\title{
Sequence and partial functional analysis of canine Bcl-2 family proteins
}

\begin{abstract}
Dogs present with spontaneous neoplasms biologically similar to human cancers. Apoptotic pathways are deregulated during cancer genesis and progression and are important for therapy. We have assessed the degree of conservation of a set of canine Bcl-2 family members with the human and murine orthologs. To this end, seven complete canine open reading frames were cloned in this family, four of which are novel for the dog, their sequences were analyzed, and their functional interactions were studied in yeasts. We found a high degree of overall and domain sequence homology between canine and human proteins. It was slightly higher than between murine and human proteins. Functional interactions between canine pro-apoptotic Bax and Bak and anti-apoptotic Bcl- $\mathrm{x}_{\mathrm{L}}, \mathrm{Bcl}-\mathrm{w}$, and Mcl-1 were recapitulated in yeasts. Our data provide support for the notion that systems based on canine-derived proteins might faithfully reproduce Bcl-2 family member interactions known from other species and establish the yeast as a useful tool for functional studies.
\end{abstract}

Key words: Bcl-2 family; canine; cloning; comparative sequence analysis; functional yeast study 


\section{Introduction}

Rodent models, including genetically modified mice and xenografts in immunocompromised mice, are indispensable tools for cancer research (Rosol et al., 2003; Kelland, 2004; Sharpless and Depinho, 2006). They have evolved in recent years to a vast array of sophisticated models that are continuously broadening and deepening our knowledge of cancer biology (Cheon and Orsulic, 2011; Ruggeri et al., 2014). A number of limitations in the use of mice, however, have become apparent in recent years. These limitations include the restricted genetic diversity inherent to mouse laboratory strains as well as substantial differences between humans and mice in certain molecular regulatory pathways, both factors with potential impact on murine tumorigenesis models (Jacks, 1996; Balmain, 2002; Hahn and Weinberg, 2002; Young and Longmore, 2004; Cheon and Orsulic, 2011). Xenografts in immunocompromised mice are widely used for preclinical drug development (Kelland, 2004) although these animals provide a completely different microenvironment for tumor growth than the original host. In addition to a limited suitability for modeling metastasis, xenograft models offer a "reductionist" view since the cells used represent only a small selection of all possible combinations of genetic and epigenetic alterations leading to a certain morphological tumor subtype (Sharpless and Depinho, 2006).

Spontaneous canine neoplasms offer the opportunity to complement data from rodents. Cancer is the most common cause of death in dogs (Vail and MacEwen, 2000). Canines, similarly to humans, constitute an outbred population with a much broader genetic background than rodent laboratory strains. In addition, canines are genetically more closely related to humans than rodents as shown from whole genome comparisons of the three species (Lindblad-Toh et al., 2005), which is also reflected by a greater similarity at the metabolic level. Canines develop a range of spontaneous neoplasms often with histological characteristics and biologic behaviour 
similar to human tumors, including non-Hodgkin's lymphoma, soft-tissue sarcomas and osteosarcoma (Vail and MacEwen, 2000; Rosol et al., 2003; Khanna et al., 2004). Dogs share a common environment with people. Because of their increasing significance as companion animals, canine tumor patients are increasingly subjected to therapy and hence provide a yet underexploited resource for modeling both pathogenetic and therapy-related aspects of human cancer.

Deregulated apoptosis is a hallmark of cancer (Hanahan and Weinberg, 2000) and plays roles in tumorigenesis and the development of resistance to therapy (Johnstone et al., 2002). The B-cell lymphoma-2 (Bcl-2) family is a large group of proteins which exert a key regulatory function in intrinsic apoptosis by controlling the integrity of the outer mitochondrial membrane (Cory and Adams, 2002). The family encompasses three major subgroups with different functions and displaying different subsets of conserved sequence motifs known as Bcl-2 homology $(\mathrm{BH})$ domains which are the hallmark of this protein family (Kelekar and Thompson, 1998; Daniel et al., 2003). Most anti-apoptotic members (which comprise Bcl-2, Bcl- $\mathrm{x}_{\mathrm{L}}, \mathrm{Bcl}-\mathrm{w}, \mathrm{Mcl}-1$ and A1) contain BH domains 1 to 4 . The multidomain pro-apoptotic members (Bax, Bak and Bok) are required for the execution of apoptosis through the mitochondrial pathway (Wei et al., 2001) and contain BH domains 1 to 3 (Chan and Yu, 2004). The third subgroup is composed of several pro-apoptotic molecules (including Bad, Noxa and many others) called BH3-only proteins since they display only the BH3 domain. They either inhibit the anti-apoptotic members or activate the multidomain pro-apoptotic members. Following an appropriate apoptotic stimulus, the characteristic balance between anti-apoptotic and multi-domain pro-apoptotic members of normal cells is perturbed. As a result, the complete pro-apoptotic molecules oligomerize and form channels in the outer mitochondrial membrane which allow the release of apoptogenic factors (e.g. cytochrome c) from the intermembranous mitochondrial space into the cytosol (Westphal et al., 2011). 
Subsequently, specific proteolytic enzymes, the caspases, are activated and elicit the demise of the cell. The $\mathrm{BH}$ domains are the basis for the interactions between the members: a hydrophobic groove formed by specific residues of the $\mathrm{BH} 1, \mathrm{BH} 2$ and $\mathrm{BH} 3$ domains of the anti-apoptotic members interacts with the amphipathic helix of the $\mathrm{BH} 3$ domain of molecules of other subgroups (Cory and Adams, 2002). Comparatively little information is available, however, on this protein family and other molecules involved in apoptosis in canines. A small number of Bcl-2 family members have been cloned and partially characterized in the dog, including the complete coding sequences for Bcl-2, Bcl-xL, Mcl-1 and Bax (Sano et al., 2003; Sano et al., 2004). Differences at the molecular level within the intrinsic apoptotic pathway between humans and dogs have been reported in rare instances. For example, a consensus Akt phosphorylation site in human caspase-9 reported to mediate suppression of apoptosis is lacking in the dog (Cardone et al., 1998; Rodriguez et al., 2000). However, awareness of such variations is important because on one side they possibly impinge on the function of the pathway under physiological and neoplastic conditions, on the other side they may interfere with targeted therapies.

The budding yeast Saccharomyces (S.) cerevisiae has been extensively used to functionally characterize human and murine Bcl-2 family members. Toxicity of Bax expression for yeasts and its abrogation by coexpression of Bcl-2, Bcl- $\mathrm{x}_{\mathrm{L}}$ and Mcl-1 first became evident in yeast two-hybrid studies of mammalian Bcl-2 family members (Sato et al., 1994). Subsequent investigations have shown that the mechanisms leading to yeast cell death caused by Bax partly rely on ancestral programmed cell death (PCD) machinery components (Ligr et al., 1998; Khoury and Greenwood, 2008). Several agents can induce yeast PCD, including hydrogen peroxide, UV radiation, the absence of nutrients, hyperosmotic stress, acetic acid and aging (Farrugia and Balzan, 2012). Yeast PCD share some phenotypical and biochemical similarities with mammalian apoptosis, including the release of mitochondrial cytochrome c 
into the cytosol (Ludovico et al., 2002). This particular phenomenon - a hallmark of mammalian Bax action - has been demonstrated following Bax expression in yeast (Manon et al., 1997). To date, several studies of mammalian Bcl-2 family proteins in S. cerevisiae have focused on genetic analyses of Bax, Bcl- $x_{\mathrm{L}}$ and $\mathrm{Bcl}-2$, while this model has rarely been used, if at all, to characterize further members such as Bak, Bcl-w, and Mcl-1 for instance (Bodrug et al., 1995; Tao et al., 1997; Beaumont et al., 2013).

In order to contribute to ongoing efforts in developing the canine model as a tool for cancer research, we herein perform an analysis of the sequences, some of which are novel for the dog, and study the function in the yeast, of selected canine Bcl-2 family proteins. 


\section{Materials and methods}

\subsection{Cell lines and cultures}

The Madin-Darby canine kidney (MDCK) cell line originates from an adult female Cocker Spaniel dog and it was purchased from the American Type Culture Collection (ATCC) (www.ATCC.org/). The cells were grown in Iscove's Mod. Dulbecco's Medium (Sigma, St. Louis, USA) supplemented with $10 \%$ fetal calf serum inactivated at $60^{\circ} \mathrm{C}, 2.5 \%$ HEPES buffer (Sigma, St. Louis, USA), 1\% L-Glutamine (Sigma, St. Louis, USA) and 1\% PenicillinStreptomycin solution (Sigma, St. Louis, USA). The canine normal keratinocyte line used originates from the skin of a healthy Beagle dog (Kolly et al., 2005). The cells were grown in Dulbeccos' Modified Eagles Medium (Sigma, St. Louis, USA) supplemented with 1\% nonessential amino acids, $1 \%$ sodium pyruvate, $1 \%$ penicillin/streptomycin and $15 \%$ fetal calf serum. All cell culture reagents were obtained from Gibco BRL life Sciences (Basel, Switzerland). Both cell lines were grown at $37^{\circ} \mathrm{C}$ and a $5 \% \mathrm{CO}_{2}$ atmosphere.

\subsection{RNA extraction, RT-PCR and cloning}

Total RNA was isolated from MDCK cells and/or from normal canine keratinocytes with the RNeasy Mini Kit (Qiagen, Hilden, Germany) according to the manufacturer's protocols. Then 40 U Protector RNAse Inhibitor (Roche, Mannheim, Germany) was added to each RNA extract. cDNA was synthesized from $1 \mu \mathrm{g}$ of total RNA using the 1st strand cDNA Synthesis Kit for RT-PCR (AMV) and an oligo-dT-primer according to the manufacturer's instructions (Roche, Mannheim, Germany).

Primers including the putative Start and Stop codons as deduced from publicly available sequence information and taking the human sequence as a reference (Tables 1 and 2) were designed either manually or by using the Primer3 website (http://frodo.wi.mit.edu/) (Rozen and 
Skaletsky, 2000). Reverse transcription PCR reactions were accomplished with $1 \mu 1$ of cDNA samples and Platinum Taq DNA Polymerase High Fidelity (Invitrogen, Carlsbad, CA, USA). Basic cycling parameters were as follows: initial denaturation at $94{ }^{\circ} \mathrm{C}$ for $1.5 \mathrm{~min} ; 35$ cycles of denaturation at $94{ }^{\circ} \mathrm{C}$ for $50 \mathrm{sec}$, annealing for $50 \mathrm{sec}$ at $50-70{ }^{\circ} \mathrm{C}$ (a gradient was chosen on dependance of the primer melting temperature) and extension at $72{ }^{\circ} \mathrm{C}$ for a time adjusted to the expected size of the product ( 1 min per $1000 \mathrm{bp}$ ); final extension for $10 \mathrm{~min}$ at $72{ }^{\circ} \mathrm{C}$. Each PCR reaction was optimized by adjusting the annealing temperature and the final magnesium concentration to yield a band with the size corresponding to the expected principal transcript for each molecule. After agarose gel separation, the amplificates obtained were recovered with MinElute Gel Extraction Kit (Qiagen, Hilden, Germany) and sent to a company (Microsynth AG, CH-9436 Balgach) for direct sequencing (Cycle Sequencing / Capillary Electrophoresis) with the primers used for amplification. If the amplification product corresponded to the expected sequence, the PCR was repeated using primers containing restriction enzyme sites suitable for cloning into the GST-tagged pGEX-4T2 vector (Invitrogen, Carlsbad, USA). Amplicons were cloned and transformed into DH5 alpha competent cells. Miniprep plasmid DNA was sequenced (Microsynth AG, CH-9436 Balgach) using the pGEX 5'- and 3'sequencing primers indicated by the manufacturer. Final cDNA sequences were derived from the consensus of at least three individual clones and were deposited in GenBank (Table 2). The correct identity of the clones was further confirmed at the protein level with immunoblot analyses with appropriate antibodies using lysates of transformed BL-21 Star E. coli harvested after induction with beta-D-thiogalactopyranoside as previously described by Keller et al. (2007). 


\subsection{Computational analysis}

Putative canine protein sequences were derived from the cDNA sequences using a translation tool accessed via the ExPASy homepage (http://www.expasy.org/). Canine nucleotide coding sequences (cds) and deduced protein sequences were compared with human and murine counterparts (Table 2) using the EMBOSS sequence analysis tool provided by the European Bioinformatics Institute (http://www.ebi.ac.uk/emboss/align/). The nucleotide and the protein sequences were aligned with the needle method and the Blosum62 matrix algorithm, respectively. The exon/intron structure was derived by aligning the cds with the respective genome sequence using Splign, a mRNA-to-genomic alignment program available at NCBI (http://www.ncbi.nlm.nih.gov/) and confirmed using BLAT (Blast like alignment tool) on the MGC genome browser (http://mgc.ucsc.edu/) (Kent, 2002). The genomic sequence releases were CanFam3.1 [GCF_000002285.2] for canines, Mus musculus GRCm38.p1 [GCF_000001635.21] for murines, and [GCF_000001405.22 GCF_000306695.1 GCF_000002135.2 GCF_000002125.1] for humans. For domain comparisons we used human domain signatures indicated in UniProtKB/Swiss-Prot and additional relevant features as suggested from the literature.

\subsection{Subcloning and expression in S. cerevisiae}

The cDNAs containing the cds for the canine multidomain pro-apoptotic proteins Bax and Bak and the anti-apoptotic proteins Bcl- $\mathrm{x}_{\mathrm{L}}, \mathrm{Bcl}-\mathrm{w}$, and $\mathrm{Mcl}-1$ were subcloned by sticky-end ligation in a yeast expression vector (epitope tagging vector pESC, Invitrogen) containing the URA3 selection marker. This vector contains two multiple cloning sites which are located downstream of the galactose inducible divergent promoters GAL1 and GAL10, respectively. Each cDNA was introduced individually in the vector. In addition, vectors were constructed with Bax or Bak paired with each one of the cDNAs for the anti-apoptotic proteins. Proper introduction of 
the cDNAs was verified by sequencing (Microsynth AG, CH-9436 Balgach) miniprep plasmid DNA using the pESC 5'- and 3'-sequencing primers indicated by the manufacturer. The yeast used throughout this study was strain BY4743 4his3/leu2/met15/ura3 purchased from Euroscarf (D-60438 Frankfurt; Acc. No. Y20000). It was routinely cultured in YPAD (1\% yeast extract, 2\% Bacto peptone, 2\% glucose, $40 \mathrm{mg}$ Adenine sulfate) medium as described (Guscetti et al., 2005). The yeasts were transformed by electroporation in presence of $1 \mathrm{M}$ sorbitol (Gene Pulser with Pulse Controller, Bio-Rad) according to a previously described protocol (Becker and Lundblad, 1994) with the empty plasmid and all plasmids described above. Selection was done on minimal $2 \%$ glucose medium without the selection marker URA. To monitor the effect of expression of the Bcl-2 family proteins, transformed yeasts were grown under aerobic conditions (shaken at $220 \mathrm{rpm}, 30{ }^{\circ} \mathrm{C}$ ) in $3 \mathrm{ml}$ of liquid minimal medium containing $2 \%$ galactose (inducing) instead of glucose (repressing) and the optical density at $600 \mathrm{~nm}\left(\mathrm{OD}_{600}\right)$ was measured every 6 hours until saturation. Each experiment was carried out in duplicate. In addition, a clonogenic assay was carried out by plating aliquots of 500 cells on minimal glucose medium, each in triplicate, after growth in inducing liquid medium for 24 and 48 hours as previously described (Guscetti et al., 2005). All clonogenicity experiments were carried out at least in three independent instances. Statistical significance of clonogenicity data for yeasts expressing either Bax or Bak alone vs. all other proteins either individually or in combination was calculated by the student's $t$ test. Significance was set at a value of $p=0.05$.

\subsection{Western Blots}

To verify expression of the respective protein after induction, representative culture samples collected at $24 \mathrm{~h}$ or $48 \mathrm{~h}$ after start of induction were analysed by western blot as previously described with minor modifications (Dettwiler et al., 2013). Briefly, protein extracts were prepared by mechanical lysis of the yeast cells (mixed to equal volumes of a lysis buffer 
containing $100 \mathrm{mM}$ Tris-HCl at $\mathrm{pH} 6.8,10 \%(\mathrm{v} / \mathrm{v})$ glycerol, 3\% (w/v) SDS, 5\% (v/v) 2mercaptoethanol and 1\%(w/v) bromophenol blue using glass beads and a Vortex mixer at maximum speed for $2 \mathrm{~min}$. The extracts were run on $12 \% \mathrm{SDS}$-polyacrylamide gels, transferred to PVDF membranes (Immobilon-P Transfer Membrane, Millipore Corporation, Billerica, MA) by electroblotting. Following primary antibodies, all previously shown to cross-react with the recombinant canine protein expressed in bacteria, were used: anti-human Bax Ab-1 mouse monoclonal antibody, clone 2D2 (cat. no. MS-711-P0, Lab Vision Corporation, Thermo Fisher Scientific, Fremont, CA 94539, USA), applied at $0.5 \mathrm{ug} / \mathrm{ml}$; anti-human Bak rabbit polyclonal antibody (cat. no. 06-536, Merck Millipore, Billerica, MA 01821, USA), applied in a 1:400 dilution; anti-mouse Bcl- $\mathrm{x}_{\mathrm{L}} \mathrm{Ab}-2$ mouse monoclonal antibody, clone 7D9 (cat. no. MS-1334PO, Lab Vision Corporation, Thermo Fisher Scientific, Fremont, CA 94539, USA), applied at $0.5 \mathrm{ug} / \mathrm{ml}$; anti-human Bcl-w (16-29) rabbit polyclonal antibody (cat. no. 197209, Merck Chemicals Ltd., San Diego, CA 92121, USA), applied in a 1:400 dilution; and anti-human Mcl1 rabbit polyclonal antibody (cat. no. HPA008455-100UL, Atlas Antibodies AB, SE-106 91 Stockholm, Sweden), applied in a 1:400 dilution. After incubation with the appropriate primary antibodies, horseradish-peroxidase labelled secondary antibodies were applied and binding was visualised using a chemiluminescent substrate. The PageRulerTM Plus Prestained Protein Ladder (Fermentas Life Sciences, Lot 00070238; Thermo Fisher Scientific, Fremont, CA 94539, USA) was used to assess protein sizes. 


\section{Results}

3.1. Nucleotide sequence comparison of canine Bcl-2 family members with the human and murine orthologues

We have identified and cloned the coding sequence (cds) of seven canine Bcl-2 family members. Three sequences (Bcl-x, Bax and Mcl-1) have previously been reported by others (Sano et al., 2003; Sano et al., 2004), the remaining four (Bcl-w, Bak, Bad and Noxa) are novel for the dog and have been deposited in GenBank. All sequence accession numbers are indicated in Table 2. In this section we report basic data derived from our cDNA clones, and, for the sake of completeness, from the complete mRNA sequence for canine Bcl-2 previously deposited in GenBank by others. Alignment of the sequences with the dog genome showed $100 \%$ identity and canonical splice sites except where otherwise stated. Expected amino acid exchanges resulting from base mismatches are mentioned. In addition, a comparison with the reference sequences of the human and murine counterparts is presented (Table 3 ).

Bcl-2 isoform $\alpha$. The canine complete mRNA sequence for Bcl-2 available from GenBank was derived from peripheral mononuclear blood cells of an adult dog. The dog genome sequence displays a gap in the region containing the Bcl-2 gene resulting in 102 bases of the cds (from base 157 through 258) that could not be aligned. Mismatches were observed at positions 146 ( $\mathrm{T}$ instead of $\mathrm{C}$ as in the genome sequence, resulting in a Phe instead of a Ser), 148 ( $\mathrm{T}$ instead of G, resulting in a Ser instead of an Ala), 327 (C instead of G), 330 (C instead of $\mathrm{T}$ ) and 441 ( $\mathrm{T}$ instead of $\mathrm{C}$ ) of the cds. In addition a single base insertion was found at position 331 (G, eliciting a frame shift) of the cds. Comparison with the human Bcl-2 isoform $\alpha$ cds (720 bp) revealed $92 \%$ identity for the canine sequence (720 bp) which is close to the homology observed between human and murine (711 bp) sequences $(89 \%)$. 
$B c l-x_{L}(B C L 2 L 1)$. The complete mRNA sequence for the canine anti-apoptotic Bcl-2 family member Bcl- $\mathrm{x}_{\mathrm{L}}$ available in GenBank was derived from lymphocytes of an adult dog. All our own clones (source: MDCK cells) showed a single nucleotide mismatch (C instead of $\mathrm{T}$ ) at position 666 of the cds when compared to the GenBank sequence. The dog genome reference sequence indicates a $\mathrm{C}$ at this position. In all three species, the $\mathrm{Bcl}-\mathrm{x}_{\mathrm{L}} \mathrm{cds}(702 \mathrm{bp})$ is distributed over two exons. Overall, canines show a slightly higher homology with humans than with mice (97\% and 94\%, respectively).

$B c l-w$ (BCL2L2). The cds of the canine anti-apoptotic Bcl-2 family member Bcl-w generated in this study (source: MDCK cells) is, like the human and murine cds, $582 \mathrm{bp}$ long and distributed over two exons. The identity of the canine Bcl-w cds with its human counterpart is $95 \%$, while the identity between human and mouse is $94 \%$.

Mcl-1. The complete mRNA sequence for the canine anti-apoptotic Bcl-2 family member Mcl1 available in GenBank was derived from lymphocytes. Alignment of this sequence with our Mcl-1 cds (source: MDCK cells) showed a one base deletion, a one base insertion and four single nucleotide mismatches. Alignment of our sequence with the dog genome indicated one nucleotide mismatch at position 436 ( $\mathrm{C}$ instead of $\mathrm{T}$ ) in our sequence. Alignment of the GenBank cds with the dog genome revealed a single bp insertion at position 31 and a single base deletion $9 \mathrm{bp}$ further on as well as five mismatches at positions 6 (T instead of C), 119 (G instead of A), 436 (C instead of T), 641 (A instead of G) and 978 (C instead of T). Two of these mismatches would lead each to a amino acid (aa) substitution (position 119: Arg instead of Lys; position 641: Gln instead of Arg), the latter involving the BH3-domain. The insertion at position 31 leads to a short frameshift resulting in the exchange of aa 11-13 (Arg-Thr-Gln instead of Gly-Leu-Asn); this region does not code for any known domain. In both humans and dogs, the Mcl-1 cds encompasses 1053 bp, in contrast to 996 bp in mice. In all three species 
investigated, the cds is distributed over three exons. The canine cds shares a higher homology with the human counterpart than the murine sequence ( $89 \%$ and $83 \%$ identity, respectively). Bak (BAK1). The cds of the canine multi-domain pro-apoptotic Bcl-2 family member Bak generated in this work (source: MDCK cells) consists, like its human counterpart, of $636 \mathrm{bp}$ distributed over five exons. The murine cds is six bp shorter (630 bp). The human sequence is more similar to the canine than to the murine sequence ( $90 \%$ and $80 \%$ identity, respectively). Bax variant $\alpha$. The mRNA sequence comprising the complete cds of Bax available in GenBank was derived from a canine osteosarcoma cell line. Our own cds sequence is $100 \%$ identical to the GenBank sequence. The dog genome sequence displays a gap in the region containing the bax gene; where proper alignement was possible (position 1 through 477 of the cds) our sequence (source: MDCK cells) was $100 \%$ identical to the genome sequence. In all three species investigated, the cds is 579 bp long. In murines and humans it is distributed over six exons. The cds of both dogs and mice show a similar degree of homology with the human Bax var. alpha (93\% and 90\% identity, respectively). We additionally detected a splice form of the canine Bax cds, which is similar to the human Bax $\gamma$ version (GenBank accession no. NM_138762). Like its human counterpart, the cds consists of $126 \mathrm{bp}$ divided into two exons. It shares 91\% identity with the human Bax $\gamma$ cds. In silico translation predicts, like in humans, an hypothetical protein of 41 aa (identity human/canine: $83 \%$ ).

Bad. The cds of the canine BH3-only Bcl-2 family member Bad generated from MDCK cells in this study consists of three exons, spanning $504 \mathrm{bp}$ in length. This is three bp shorter than the human cds and 111 bp shorter than the murine cds, which spans over four exons. Since several gaps occur in the alignment between human and canine cds, we generated additional clones from a normal canine keratinocyte cell line (Kolly et al., 2005) to exclude a MDCKrelated artifact. Clones from both cell types yielded the same sequence. The canine Bad cds is $86 \%$ identical to its human counterpart, whereas the identity between human and mouse is only 
$65 \%$, due to the additional coding exon at the 5 '-end in the murine sequence. When only overlapping parts were compared, identity between human and mouse sequences was $82 \%$. Noxa (PMAIP1). The cds of the canine BH3-only Bcl-2 family member Noxa, generated from a normal canine keratinocyte cell line (Kolly et al., 2005) in this study, is distributed, like its human counterpart, over two exons with a total of $165 \mathrm{bp}$. It yields $87 \%$ identity with the human sequence. The murine cds is divided into three exons and spans $312 \mathrm{bp}$. The mouse sequence differs remarkably from the human ( $40 \%$ identity), which ensues from the presence of an additional coding exon at the 5 '-end in the murine sequence. Comparison of overlapping parts only yielded $70 \%$ identity between human and mouse sequences.

\subsection{Protein sequence comparison of canine Bcl-2 family members with the human and murine} orthologues

We further analyzed in silico the protein sequences of the canine Bcl-2 members as deduced from the nucleotide sequences described above. The degree of conservation between humans, canines and mice of the whole proteins as well as of the most relevant domains, motifs and residues were determined (Table 4). All sequences and respective alignments are reported in Supplemental Figure 1.

The overall identity of these proteins ranged from $76 \%$ to $100 \%$ between canines and humans, and from $34 \%$ to $99 \%$ between mice and humans. In all but one (Bcl-2 isoform alpha)cases there was a higher degree of homology between human and canine sequences than between human and murine sequences. The length of the Bcl-2 family proteins is relatively conserved in canines compared to humans, while it markedly differs for some murine proteins, in particular the BH3-only members Bad and Noxa. The anti-apoptotic family members are best conserved, with the two proteins Bcl- $\mathrm{x}_{\mathrm{L}}$ and $\mathrm{Bcl}-\mathrm{w} 100 \%$ identical at the amino acid (aa) level between humans and dogs. In murines, three out of $15 \mathrm{Bcl}-2$ Homology $(\mathrm{BH})$ domains analyzed 
in this subgroup differed from the human counterpart by one aa, while there were no differences in dogs. The transmembrane domains showed either $100 \%$ conservation in all three species $\left(\mathrm{Bcl}-\mathrm{x}_{\mathrm{L}}, \mathrm{Bcl}-\mathrm{w}, \mathrm{Mcl}-1\right)$ or slight differences with the human counterpart in the canine version (Bcl-2). The multi-domain pro-apoptotic members Bak and Bax showed a slightly lower degree of interspecies conservation than the anti-apoptotic members. In the mouse, all BH domains of these two molecules showed at least one aa exchange, three $\mathrm{BH}$ domains showed two aa exchanges. In the dog only two out of these six BH domains showed one aa exchange. The transmembrane domain of Bax is $100 \%$ conserved across the three species, that of Bak shows an exchange of four aa in mice and of two aa in dogs. Interestingly, the lowest overall and domain identity in the Bcl-2 family was observed with the two BH3-only proteins Bad and Noxa. This is particularly true for the murine molecules which are markedly longer than the canine and human counterparts. Comparison of these proteins between murines and humans yielded 58\% and 34\% identity for Bad and Noxa, respectively (while their overlapping regions showed $73 \%$ and $64 \%$ identity, respectively).

Several human Bcl-2 family proteins present with cleavage sites for caspase-3 and other proteases. Figure 1 shows the comparative tetramer sequences preceding cleavage sites reported in the literature. Sequences $100 \%$ conserved in all three species include both caspase3 cleavage sites of Bcl- $\mathrm{x}_{\mathrm{L}}$, the major caspase-3 cleavage sites of Mcl-1 and of Bad, and the calpain recognition sequence of Bax (Cheng et al., 1997; Clem et al., 1998; Fujita et al., 1998; Wood et al., 1998; Condorelli et al., 2001; Michels et al., 2004).

\subsection{Partial functional characterization of canine Bcl-2 family proteins in the yeast $S$.} cerevisiae

In this part we functionally analyzed interactions of a subset of canine Bcl-2 family members comprising the multidomain pro-apoptotic proteins Bax and Bak and the anti-apoptotic 
proteins Bcl- $\mathrm{x}_{\mathrm{L}}, \mathrm{Bcl}-\mathrm{w}$ and Mcl-1 in the yeast model $S$. cerevisiae. First, the proteins were expressed in inducing liquid media containing galactose, and yeast cell growth was monitored by measuring the $\mathrm{OD}_{600}$ at $6 \mathrm{~h}$ intervals. As expected, compared to yeasts containing the empty vector, cultures of yeasts expressing either Bax or Bak showed a growth delay, while the growth of yeasts expressing any of the anti-apoptotic proteins was unaffected (Fig. 2a). The growth delay caused by Bax or Bak was completely abrogated when any of the anti-apoptotic proteins was expressed concomitantly (Fig. 2b). This kind of growth delay has previously been described for human and/or murine Bax and Bak, and it has been attributed to reproductive cell death (Ligr et al., 1998; Xu et al., 1999; Guscetti et al., 2005). This notion was herein confirmed for the canine orthologs by using a clonogenic assay following 24 and 48 hours of protein expression. The data is presented in Fig. 3a and 3b. Expression of either Bak or Bax alone resulted in a reduction of the percentage of viable and reproduction-competent yeasts to 20$10 \%$ (Bak) or $3-1 \%(\mathrm{Bax})$ of yeasts carrying the empty vector. In contrast, $\mathrm{Bcl}-\mathrm{x}_{\mathrm{L}}$ and $\mathrm{Mcl}-1$ showed a slight degree of toxicity which was most apparent at $48 \mathrm{~h}$ of expression (Fig. 3b). The effect of Bax and Bak was abrogated through concomitant expression of each of the antiapoptotic proteins Bcl-w, Bcl- $\mathrm{x}_{\mathrm{L}}$, and $\mathrm{Mcl}-1$. Extracts from yeasts transformed with the corresponding cDNAs showed distinct bands for each protein in Western blots indicating their expression (Fig. 4). 


\section{Discussion}

We have carried out a comparative sequence analysis of a representative number of canine Bcl2 family members, at both the nucleotide and protein level. A high sequence homology was found between the canine proteins and their human and murine counterparts. Notably, the canine sequences showed a higher degree of homology with the human sequences than the murine sequences, which is consistent with a faster mutation rate in mice as compared to dogs and people (Lindblad-Toh et al., 2005) and supports in principle the dog as a model organism for diseases involving deregulation of mitochondrial apoptosis. Bcl-2 family proteins have been assigned a central importance in the pathogenesis of various human cancer syndromes (Kelly and Strasser, 2011; Nys and Agostinis, 2012). Likewise, they have been implicated in the pathogenesis of diverse canine tumors including for instance hemangiosarcoma, mammary tumors, tumors of neural and hematopoetic origin (Sano et al., 2003; Kumaraguruparan et al., 2006a; Kumaraguruparan et al., 2006b; Yan et al., 2006; Murakami et al., 2008; Ide et al., 2010; Strefezzi et al., 2012; Dettwiler et al., 2013).

Proteins are assigned to the Bcl-2 family owing to the presence of at least one of four $\mathrm{BH}$ domains (Kelekar and Thompson, 1998; Daniel et al., 2003). These domains mediate the interplay between the Bcl-2 family members, which controls the integrity of the mitochondrial membrane. Structural studies have shown the basis for interactions between the different subgroups (Cory and Adams, 2002). The fact that several domains participate in forming a functionally important scaffold-like structure might explain the limited overall and domain interspecies variation found in anti-apoptotic members of the Bcl-2 family. In contrast, the BH3-only members Bad and Noxa showed the least degree of overall interspecies conservation. This might derive from the fact that the BH3-only subgroup members exert their apoptosisrelated function through one single domain as opposed to members of the other subgroups. 
Both murine Bad and Noxa significantly differ from their human and canine counterparts by displaying an additional coding exon. In addition, murine Noxa displays a second BH3-domain motif (Oda et al., 2000). In contrast, regulatory serine residues (Ser ${ }^{75,99,118,134}$ in humans) in Bad are conserved among the three species at nearly the same locations. Phosphorylation of these residues upon a pro-survival stimulus maintains Bad in an inactive state and bound to cytosolic 14-3-3Sigma proteins (Bae et al., 2001). Recent studies have revealed that the antiapoptotic members of the Bcl-2 family each bear a unique pattern of interaction with peptides derived from $\mathrm{BH} 3$ domains of BH3-only molecules (Certo et al., 2006) providing the basis for the development of therapeutic compounds targeting these interactions (Liu and Wang, 2012). The strong degree of conservation of the dog proteins suggest that this species is potentially well-suited for modeling interactions of Bcl-2 family members and related therapeutic peptides.

Apoptosis is executed through cleavage of proteins at specific recognition sites through specific proteases, mainly through caspases (Cory and Adams, 2002). Several members of the Bcl-2 protein family display protease cleavage sites, and their cleavage products have been shown in general to enhance apoptotic activity (Cheng et al., 1997; Clem et al., 1998; Fujita et al., 1998; Wood et al., 1998; Condorelli et al., 2001; Michels et al., 2004) and in some cases to mediate apoptotic activity (Ofengeim et al., 2012). Sequence comparison between human, canine and murine Bcl-2 family members has revealed a number of fully conserved cleavage sites. Some of the remaining cleavage sites conserved to less than $100 \%$, such as e.g. the motif present in canine Bcl-2, might still be functional based on the sequence, while others, such as for example the minor cleavage site of Bad, are likely not functional. The impact of sequence variants on function should be verified experimentally. Conservation of protease recognition motifs across species support their biological relevance on one side and the validity of the canine model on the other side. 
Comparison of the sequences generated in this study with the canine genome sequence as well as with mRNA sequences previously submitted to Genbank by others revealed a generally high degree of concordance. Except for the gap in the genome sequence in the region coding for Bax and for a single base mismatch in the cds of Mcl-1 all sequences generated in this study (4119 bases) were 100\% identical with the dog genome sequence. Another gap in the genome sequence hindered proper alignment of the Bcl-2 cds available from Genbank. Nevertheless, the dog genome third release coverage has been estimated at $99.8 \%$ of the euchromatic portion of the genome, and the rate of sequencing errors within genes has been drastically reduced compared to the previous release (Lindblad-Toh et al., 2005; Hoeppner et al., 2014). Mismatches either represent sequencing errors, single nucleotide polymorphisms, somatic cell variation, or RNA editing (Furey et al., 2004). All of our novel cds were also predicted by the automated prediction program GNOMON at NCBI with the exception of Noxa. In addition, the automated program predicted an additional sequence at the 5'-end of canine Bad that was not supported by own 5'-RACE data (data not shown). Comparisons of previous GenBank entries with the dog genome revealed conspicuous mismatches for Bcl-2 and Mcl-1. An analysis of approximately 30,000 non-redundant human mRNA sequences suggested that mRNA collections may contain a substantial number of errors (Furey et al., 2004).

We have used the well-characterized eukaryotic yeast $S$. cerevisiae for the expression and functional analysis of the canine Bcl-2 proteins cloned herein. This unicellular organism is easy to manipulate genetically and it has previously been extensively used for functional studies of human Bcl-2 family proteins since considered to be devoid of homologs of the Bcl2 family (Fleury et al., 2002; Priault et al., 2003; Guscetti et al., 2005; Khoury and Greenwood, 2008). This notion has recently been questioned since the description of a yeast protein variously referred to as Bxilp (Bax inhibitor-1) or Ybh3p (Yeast BH3-only protein) (Büttner et al., 2011; Cebulski et al., 2011). However, while its classification and function are 
still debated, it did not visibly interfere with the experiments in this study. Expression of canine Bcl-2 family members in yeast has not been described before. Here, we successfully performed a functional analysis of five canine Bcl-2 family members in this model organism, namely the pro-apoptotic members Bak and Bax and the anti-apoptotic members Bcl-w, Bcl$\mathrm{xL}$ and Mcl-1. As previously described for the human and/or murine orthologs (Ink et al., 1997; Tao et al., 1997; Ligr et al., 1998), expression of canine Bak and Bax showed a lethal effect in yeast. Moreover, this effect was abrogated on co-expression of the anti-apoptotic members Bcl-xL, Mcl-1 and Bcl-w as previously demonstrated for large part of their human orthologs in yeast (Tao et al., 1997; Beaumont et al., 2013). To our knowledge, abrogation of the effect of Bak by Bcl-w has not been previously reported in this model. We therefore consider the yeast system as suitable for the functional assessment of canine Bcl-2 family members and their interactions. Future use of the model could encompass e.g. the addition of BH3-only proteins (Guscetti et al., 2005) or the comparative exploration of the effects of specific compounds on interactions between Bcl-2 family members of canine versus human origin (Silva et al., 2011) thus further assessing the potential value of the canine model. Several murine models, in particular genetically engineered mouse models, have proven invaluable for mechanistic and drug discovery studies (Cheon and Orsulic, 2011; Ruggeri et al., 2014). As a specific example, the E $\mu$-myc lymphoma model has been successfully used to model the efficacy of the Bcl-2 antagonist ABT-737 against an aggressive lymphoma subtype (Mason et al., 2008), and its derivative ABT-199 is currently tested in phase II and III studies (Besbes et al., 2015). Provided the canine and human molecules behave similarly, spontaneous dog tumors could provide an additional frame for testing such compounds in a clinical setting. 


\section{Conclusions}

In summary, we have performed a comparative as well as a functional analysis of a representative set of canine Bcl-2 family members. Our analysis revealed a high degree of sequence similarity in the canine Bcl-2 family proteins compared to their human counterparts, especially within domains. Functional interactions of selected canine multidomain proapoptotic with anti-apoptotic members were recapitulated in a yeast model. This in vitro model might provide a valuable tool for instance for testing therapies specifically targeting this protein family and, subsequently, to further establishing spontaneous dog neoplasms as models for human cancer.

\section{Acknowledgement}

The authors are greatly indebted to Prof. M. M. Suter and PD Dr. E. Müller, University of Berne, Switzerland, for providing the normal canine keratinocyte line and to Dr. L. Vaughan and Dr. A. Polkinghorne for helpful comments and technical support. This study was partly funded by a Vetsuisse grant. Vetsuisse had no role in any part of the study. 


\section{References}

Bae, J., Hsu, S.Y., Leo, C.P., Zell, K., Hsueh, A.J., 2001. Underphosphorylated BAD interacts with diverse antiapoptotic Bcl-2 family proteins to regulate apoptosis. Apoptosis 6, 319-30.

Balmain, A., 2002. Cancer as a complex genetic trait: tumor susceptibility in humans and mouse models. Cell 108, 145-152.

Beaumont, T.E., Shekhar, T.M., Kaur, L., Pantaki-Eimany, D., Kvansakul, M., Hawkins, C.J., 2013. Yeast techniques for modeling drugs targeting Bcl-2 and caspase family members. Cell death and disease 4, e619.

Becker, D.M. and Lundblad, V., 1994. Introduction of DNA into yeast cells. In: Ausuel, F.M., Brent, R., Kingston, R.E., Moore, D.D., Seidman, J.G., Smith, J.A., Struhl, K. (Eds.), Current Protocols in Molecular Biology, John Wiley \& Sons, New York, pp. 13.7.1-13.7.10.

Besbes, S., Mirshahi, M., Pocard, M., Billard, C., 2015. New dimension in therapeutic targeting of BCL-2 family proteins. Oncotarget. 2015 Apr 19 (Epu ahead of print).

Bodrug, S.E., Aimé-Sempé, C., Sato, T., Krajewski, S., Hanada, M., Reed, J.C., 1995. Biochemical and functional comparisions of Mcl-1 and Bcl-2 proteins: evidence for a novel mechanism of regulating Bcl-2 family protein function. Cell death and differentiation 2, 173-82.

Büttner, S., Ruli, D., Vögtle, F.N., Galluzzi, L., Moitzi, B., Eisenberg, T., Kepp, O., Habernig, L., Carmona-Gutierrez, D., Rockenfeller, P., Laun, P., Breitenbach, M., Khoury, C., Fröhlich, K.U., Rechberger, G., Meisinger, C., Kroemer, G., Madeo, F., 2011. A yeast BH3-only protein mediatees the mitochondrial pathway of apoptosis. The EMBO Journal 30, 2779-92. 
Cardone, M.H., Roy, N., Stennicke, H.R., Salvesen, G.S., Franke, T.F., Standbridge, E., Frisch, S., Reed, J.C., 1998., Regulation of cell death protease caspase-9 by phosphorylation. Science 282, 1318-1321.

Cebulski, J., Malouin, J., Pinches, N., Cascio, V., Austriaco, N., 2011. Yeast Bax inhibitor, Bxilp, is an ER-localized protein that links the unfolded protein response and programmed cell death in Saccharomyces cerevisiae. PLoS One 6, e20882. Doi: 10.1371.

Certo, M., Del Gaizo Moore, V., Nishino, M., Wei, G., Korsmeyer, S., Armstrong, S.A., Letai, A., 2006. Mitochondria primed by death signals determine celllular addiction to antiapoptotic BCL-2 family members. Cancer Cell 9, 351-65.

Chan, S.L., Yu, V.C., 2004. Proteins of the bcl-2 family in apoptosis signalling: from mechanistic insights to therapeutic opportunities. Clinical and Experimental Pharmacology and Physiology 31, 119-28.

Cheng, E.H., Kirsch, D.G., Clem, R.J., Ravi, R., Kastan, M.B., Bedi, A., Ueno, K., Hardwick, J.M., 1997. Conversion of Bcl-2 to a Bax-like death effector by caspases. Science 278, 1966-8.

Cheon, D.J. and Orsulic, S., 2011. Mouse models of cancer. Annual Review of Pathology: Mechanisms of Disease 6, 95-119.

Clem, R.J., Cheng, E.H., Karp, C.L., Kirsch, D.G., Ueno, K., Takahashi, A., Kastan, M.B., Griffin, D.E., Earnshaw, W.C., Veliuona, M.A., Hardwick, J.M., 1998. Modulation of cell death by Bcl- $x_{L}$ through caspase interaction. Proceedings of the National Academy of Sciences of the United States of America 95, 554-559.

Condorelli, F., Salomoni, P., Cotteret, S., Cesi, V., Srinivasula, S.M., Alnemri, E.S., Calabretta, B., 2001. Caspase cleavage enhances the apoptosis-inducing effects of BAD. Molecular and Cellular Biology 21, 3025-3036. 
Cory, S., Adams, J.M., 2002. The Bcl2 family: regulators of the cellular life-or-death switch. Nature Reviews Cancer 2, 647-656.

Daniel, P.T., Schulze-Osthoff, K., Belka, C., Grüner, D., 2003. Guardians of cell death: the Bcl-2 family proteins. Essays in Biochemistry 39, 73-88.

Dettwiler, M., Croci, M., Vaughan, L., Guscetti, F., 2013. Immunohistochemical expression study of proapoptotic BH3-only protein bad in canine nonneoplastic tissues and canine lymphomas. Journal of Veterinary Pathology 50, 789-96.

Farrugia, G., Balzan, R., 2012. Oxidative stress and programmed cell death in yeast. Frontiers in Oncology 2, 64.

Fleury, C., Pampin, M., Tarze, A., Mignotte, B., 2002. Yeast as a model to study apoptosis? Bioscience Reports 22, 59-79.

Fujita, N., Nagahashi, A., Nagashima, K., Rokudai, S., Tsuruo, T., 1998. Acceleration of apoptotic cell death after the cleavage of Bcl-x $x_{L}$ protein by caspase-3-like proteases. Oncogene 17, 1295-304.

Furey, T.S., Diekhans, M., Lu, Y., Graves, T.A., Oddy, L., Randall-Maher, J., Hillier, L.W., Wilson, R.K., Haussler, D., 2004. Analysis of human mRNAs with the reference genome sequence reveals potential errors, polymorphisms, and RNA editing. Genome Research $14,2034-40$.

Guscetti, F., Nath, N., Denko, N., 2005. Functional characterization of human proapoptotic molecules in yeast S. cerevisiae. FASEB Journal 19, 464-6.

Hahn, W.C., Weinberg, R.A., 2002. Modelling the molecular circuitry of cancer. Nature Reviews Cancer 2, 331-341.

Hanahan, D., Weinberg, R.A., 2000. The hallmarks of cancer. Cell 100, 57-70.

Hoeppner, M.P., Lundquist, A., Pirun, M., Meadows, J.R., Zamani, N., Johnson, J., Sundström, G., Cook, A., FitzGerald, M.G., Swofford, R., Mauceli, E., Moghadam, B.T., 
Greka, A., Alföldi, J., Abouelleil, A., Aftuck, L., Bessette, D., Berlin, A., Brown, A., Gearin, G., Lui, A., Macdonald, J.P., Priest, M., Shea, T., Turner-Maier, J., Zimmer, A., Lander, E.S., di Palma, F., Lindblad-Toh, K., Grabherr, M.G., 2014. An improved canine genome and a comprehensive catalogue of coding genes and non-coding transcripts. PLoS One 9, e91172.

Ide, T., Uchida, K., Kikuta, F., Suzuki, K., Nakayama, H., 2010. Immunohistochemical characterization of canine neuroepithelial tumors. Veterinary Pathology 47, 741-50.

Ink, B., Zornig, M., Baum, B., Hajibagheri, N., James, C., Chittenden, T., Evan, G., 1997. Human Bak induces cell death in Schizosaccharomyces pombe with morphological changes similar to those with apoptosis in mammalian cells. Molecular and Cellular Biology 17, 2468-74.

Jacks, T., 1996. Tumor suppressor gene mutations in mice. Annual Review of Genetics 30, 603-636.

Johnstone, R.W., Ruefli, A.A., Lowe, S.W., 2002. Apoptosis: a link between cancer genetics and chemotherapy. Cell 108, 153-164.

Kelekar, A., Thompson, C.B., 1998. Bcl-2-family proteins: the role of the BH3 domain in apoptosis. Trends in Cell Biology 8, 324-30.

Kelland, L.R., 2004. Of mice and men: values and liabilities of the athymic nude mouse model in anticancer drug development. European Journal of Cancer 40, 827-836.

Keller, S.M., Schade, B., Rickenbacher, A.B., Brugnera, E., Wergin, M.C., Müller, E.J., Suter, M.M., Guscetti, F., 2007. A comprehensive test system to identify suitable antibodies against p53 for immunohistochemical analysis of canine tissues. Journal of Comparative Pathology 137, 59-70.

Kelly, P.N., Strasser, A., 2011. The role of Bcl-2 and its pro-survival relatives in tumourigenesis and cancer therapy. Cell death and differentiation 18, 1414-24. 
Kent, W.J., 2002. BLAT--the BLAST-like alignment tool. Genome Research 12, 656-664.

Khanna, C., Wan, X., Bose, S., Cassaday, R., Olomu, O., Mendoza, A., Yeung, C., Gorlick, R., Hewitt, S.M., Helman, L.J., 2004. The membrane-cytoskeleton linker ezrin is necessary for osteosarcoma metastasis. Nature Medicine 10, 182-186.

Khoury, C.M., Greenwood, M.T., 2008. The pleiotropic effects of heterologous Bax expression in yeast. Biochimica et Biophysica Acta (BBA) Molecular Cell Research $1783,1449-65$.

Kolly, C., Suter, M.M., Muller, E.J., 2005. Proliferation, cell cycle exit, and onset of terminal differentiation in cultured keratinocytes: pre-programmed pathways in control of C-Myc and Notch1 prevail over extracellular calcium signals. Journal of Investiagitve Dermatology 124, 1014-1025.

Kumaraguruparan, R., Karunagaran, D., Balachandran, C., Manohar, B.M., Nagini, S., 2006. Of humans and canines: a comparative evaluation of heat shock and apoptosis-associated proteins in mammary tumors. Clinica Chimica Acta 365, 168-76.

Kumaraguruparan, R., Prathiba, D., Nagini, S., 2006. Of humans and canines:

Immunohistochemical analysis of PCNA, Bcl-2, p53, cytokeratin and ER in mammary tumours. Research in Veterinary Science 81, 218-24.

Ligr, M., Madeo, F., Fröhlich, E., Hilt, W., Fröhlich, K.U., Wolf, D.H., 1998. Mammalian Bax triggers apoptotic changes in yeast. FEBS Letters 438, 61-65.

Lindblad-Toh, K., Wade, C.M., Mikkelsen, T.S., Karlsson, E.K., Jaffe, D.B., Kamal, M., Clamp, M., Chang, J.L., Kulbokas, E.J. 3rd, Zody, M.C., Mauceli, E., Xie, X., Breen, M., Wayne, R.K., Ostrander, E.A., Ponting, C.P., Galibert, F., Smith, D.R., DeJong, P.J., Kirkness, E., Alvarez, P., Biagi, T., Brockman, W., Butler, J., Chin, C.W., Cook, A., Cuff, J., Daly, M.J., DeCaprio, D., Gnerre, S., Grabherr, M., Kellis, M., Kleber, M., Bardeleben, C., Goodstadt, L., Heger, A., Hitte, C., Kim, L., Koepfli, K.P., Parker, H.G., 
Pollinger, J.P., Searle, S.M., Sutter, N.B., Thomas, R., Webber, C., Baldwin, J., Abebe, A., Abouelleil, A., Aftuck, L., Ait-Zahra, M., Aldredge, T., Allen, N., An, P., Anderson, S., Antoine, C., Arachchi, H., Aslam, A., Ayotte, L., Bachantsang, P., Barry, A., Bayul, T., Benamara, M., Berlin, A., Bessette, D., Blitshteyn, B., Bloom, T., Blye, J., Boguslavskiy, L., Bonnet, C., Boukhgalter, B., Brown, A., Cahill, P., Calixte, N., Camarata, J., Cheshatsang, Y., Chu, J., Citroen, M., Collymore, A., Cooke, P., Dawoe, T., Daza, R., Decktor, K., DeGray, S., Dhargay, N., Dooley, K., Dooley, K., Dorje, P., Dorjee, K., Dorris, L., Duffey, N., Dupes, A., Egbiremolen, O., Elong, R., Falk, J., Farina, A., Faro, S., Ferguson, D., Ferreira, P., Fisher, S., FitzGerald, M., Foley, K., Foley, C., Franke, A., Friedrich, D., Gage, D., Garber, M., Gearin, G., Giannoukos, G., Goode, T., Goyette, A., Graham, J., Grandbois, E., Gyaltsen, K., Hafez, N., Hagopian, D., Hagos, B., Hall, J., Healy, C., Hegarty, R., Honan, T., Horn, A., Houde, N., Hughes, L., Hunnicutt, L., Husby, M., Jester, B., Jones, C., Kamat, A., Kanga, B., Kells, C., Khazanovich, D., Kieu, A.C., Kisner, P., Kumar, M., Lance, K., Landers, T., Lara, M., Lee, W., Leger, J.P., Lennon, N., Leuper, L., LeVine, S., Liu, J., Liu, X., Lokyitsang, Y., Lokyitsang, T., Lui, A., Macdonald, J., Major, J., Marabella, R., Maru, K., Matthews, C., McDonough, S., Mehta, T., Meldrim, J., Melnikov, A., Meneus, L., Mihalev, A., Mihova, T., Miller, K., Mittelman, R., Mlenga, V., Mulrain, L., Munson, G., Navidi, A., Naylor, J., Nguyen, T., Nguyen, N., Nguyen, C., Nguyen, T., Nicol, R., Norbu, N., Norbu, C., Novod, N., Nyima, T., Olandt, P., O'Neill, B., O'Neill, K., Osman, S., Oyono, L., Patti, C., Perrin, D., Phunkhang, P., Pierre, F., Priest, M., Rachupka, A., Raghuraman, S., Rameau, R., Ray, V., Raymond, C., Rege, F., Rise, C., Rogers, J., Rogov, P., Sahalie, J., Settipalli, S., Sharpe, T., Shea, T., Sheehan, M., Sherpa, N., Shi, J., Shih, D., Sloan, J., Smith, C., Sparrow, T., Stalker, J., Stange-Thomann, N., Stavropoulos, S., Stone, C., Stone, S., Sykes, S., Tchuinga, P., Tenzing, P., Tesfaye, S., Thoulutsang, D., Thoulutsang, Y., 
Topham, K., Topping, I., Tsamla, T., Vassiliev, H., Venkataraman, V., Vo, A., Wangchuk, T., Wangdi, T., Weiand, M., Wilkinson, J., Wilson, A., Yadav, S., Yang, S., Yang, X., Young, G., Yu, Q., Zainoun, J., Zembek, L., Zimmer, A., Lander, E.S., 2005. Genome sequence, comparative analysis and haplotype structure of the domestic dog. Nature 438, 803-819.

Liu, Q. and Wang, H.G., 2012. Anti-cancer drug discovery and development: Bcl-2 family small molecule inhibitors. Communicative and integrative biology 5, 557-65.

Ludovico, P., Rodrigues, F., Almeida, A., Silva, M.T., Barrientos, A., Côrte-Real, M., 2002. Cytochrome c release and mitochondria involvement in programmed cell death induced by acetic acid in Saccharomyces cerevisiae. Molecular Biology of the Cell 13, 2598-606. Manon, S., Chaudhuri, B., Guérin, M., 1997. Release of cytochrome c and decrease of cytochrome c oxidase in Bax-expressing yeast cells, and prevention of these effects by coexpression of Bcl-x $\mathrm{x}_{\mathrm{L}}$.FEBS Letters 415, 29-32.

Mason, K.D., Vandenberg, C.J., Scott, C.L., Wei, A.H., Cory, S., Huang, D.C., Roberts, A.W., 2008. In vivo efficacy of the Bcl-2 antagonist ABT-737 against aggressive Mycdriven lymphomas. Proceedings of the National Academy of Sciences USA 105, 17961-1.

Michels, J., O'Neill, J.W., Dallman, C.L., Mouzakiti, A., Habens, F., Brimmell, M., Zhang, K.Y., Craig, R.W., Marcusson, E.G., Johnson, P.W., Packham, G., 2004. Mcl-1 is required for Akata6 B-lymphoma cell survival and is converted to a cell death molecule by efficient caspase-mediated cleavage. Oncogene 23, 4818-4827.

Murakami, M., Sakai, H., Kodama, A., Mori, T., Maruo, K., Yanai, T., Masegi, T., 2008. Expression of the anti-apoptotic factors Bcl-2 and survivin in canine vascular tumours. Journal of Comparative Pathology 139, 1-7.

Nys, K., Agostinis, P., 2012. Bcl-2 family members: essential players in skin cancer. Cancer Letters 320, 1-13. 
Oda, E., Ohki, R., Murasawa, H., Nemoto, J., Shibue, T., Yamashita, T., Tokino, T., Taniguchi, T., Tanaka, N., 2000. Noxa, a BH3-only member of the Bcl-2 family and candidate mediator of p53-induced apoptosis. Science 288, 1053-8.

Ofengeim, D., Chen, Y.B., Miyawaki, T., Li, H., Sacchetti, S., Flannery, R.J., Alavian, K.N., Pontarelli, F., Roelofs, B.A., Hickman, J.A., Hardwick, J.M., Zukin, R.S., Jonas, E.A., 2012. N-terminally cleaved Bcl- $\mathrm{x}_{\mathrm{L}}$ mediates ischemia-induced neuronal death. Nature Neuroscience 15, 574-80.

Priault, M., Camougrand, N., Kinnally, K.W., Vallette, F.M., Manon, S., 2003. Yeast as a tool to study Bax/mitochondrial interactions in cell death. FEMS Yeast research 4, 15-27.

Rodriguez, J., Chen, H.H., Lin, S.C., Lazebnik, Y., 2000. Caspase phosphorylation, cell death, and species variability. Science 287, 1363a.

Rosol, T.J., Tannehill-Gregg, S.H., LeRoy, B.E., Mandl, S., Contag, C.H., 2003. Animal models of bone metastasis. Cancer 97, 748-757.

Rozen, S., Skaletsky, H., 2000. Primer3 on the WWW for general users and for biologist programmers. Methods in Molecular Biology 132, 365-386.

Ruggeri, B.A., Camp, F., Miknyoczki, S., 2014. Animal models of disease: pre-clinical animal models of cancer and their applications and utility in drug discovery. Biochemical Pharmacology 87, 150-61.

Sano, J., Oguma, K., Kano, R., Hasegawa, A., 2003. Canine Bcl-xL gene and its expression in tumor cell lines. Journal of Veterinary Medical Science 65, 149-151.

Sano, J., Oguma, K., Kano, R., Hasegawa, A., 2004. Molecular cloning of canine Mcl-1 gene and its expression in tumor cell lines. Journal of Veterinary Medical Science 66, 709-712.

Sato, T., Hanada, M., Bodrug, S., Irie, S., Iwama, M., Boise, L.H., Thompson, C.B., Golemis, E., Fong, L., Wang, H.G., 1994. Interactions among members of the Bcl-2 protein family 
analyzed with a yeast two-hybrid system. Proceedings of the National Academy of Sciences of the United States of America 91, 9238-9242.

Sharpless, N.E., Depinho, R.A., 2006. The mighty mouse: genetically engineered mouse models in cancer drug development. Nature Reviews Drug Discovery 5, 741-754.

Silva, R.D., Manon, S., Gonçalves, J., Saraiva, L., Côrte-Real, M., 2011. The importance of humanized yeast to better understand the role of bcl-2 family in apoptosis: finding of novel therapeutic opportunities. Current Pharmaceutical Design 17, 246-55.

Strefezzi Rde, F., Kleeb, S.R., Xavier, J.G., Fukumasu, H., Catão-Dias, J.L., 2012. The value of immunohistochemical expression of BAX in formulating a prognosis for canine cutaneous mast cell tumours. Journal of Comparative Pathology 146, 314-9.

Tao, T., Kurschner, C., Morgan, J.I., 1997. Modulation of cell death in yeast by the Bcl-2 family of proteins. Journal of Biological Chemistry 272, 15547-52.

Vail, D.M., MacEwen, E.G., 2000. Spontaneously occurring tumors of companion animals as models for human cancer. Cancer Investigation 18, 781-792.

Wei, M.C., Zong, W.X., Cheng, E.H., Lindsten, T., Pnoutsakopoulou, V., Ross, A.J., Roth, K.A., MacGregor, G.R., Thompson, C.B., Korsmeyer, S.J., 2001. Proapoptotic BAX and BAK: a requisite gateway to mitochondrial dysfunction and death. Science 292, 727-730. Westphal, D., Dewson, G., Czabotar, P.E., Kluck, R.M., 2011. Molecular biology of Bax and Bak activation and action. Biochimica et Biophysica Acta 1813, 521-31.

Wood, D.E., Thomas, A., Devi, L.A., Berman, Y., Beavis, R.C., Reed, J.C., Newcomb, E.W., 1998. Bax cleavage is mediated by calpain during drug-induced apoptosis. Oncogene 17, 1069-1078.

Xu, Q., Jurgensmeier, J.M., Reed, J.C., 1999. Methods of assaying Bcl-2 and Bax family proteins in yeast. Methods 17, 292-304. 
Yan, W.Y., Liu, C.H., Chang, C.J., Lee, C.C., Chang, K.J., Lin, C.T., 2006. Proliferative activity, apoptosis and expression of oestrogen receptor and Bcl-2 oncoprotein in canine mammary gland tumours. Journal of Comparative Pathology 134, 70-9.

Young, A.P., Longmore, G.D., 2004. Differential regulation of apoptotic genes by Rb in human versus mouse cells. Oncogene 23, 2587-2599. 


\section{Supplemental Figure S1}

\section{Alignments of Bcl-2 proteins of human, canine, and murine origin and principal domains and motifs}

\section{Alignment for Bcl-2 isophorm alpha}

$\mathrm{BH} 4$

$\begin{array}{lll}\text { Human } & 1 & \text { MAHAGRTGYDNREIVMKY I HYKLSQRGYEWDAGDVGAAPPGAAPAPG IFS SQPGHTPHPA } \\ \text { Canine } & 1 & \text { MAHAGRTGYDNREIVMKY I HYKLSQRGYEWDAGEAGAAPPGAAPAPGIFS SQPGRAPAP- } \\ \text { Murine } & 1 & \text { MAQAGRTGYDNREIVMKY I HYKLSQRGYEWDAGDADAAPLGAAPTPGIFSFQPESNPMPA }\end{array}$

Human 114 EMSSQLHLTPFTARGRFATVVEELFRDGVNWGRIVAFFEFGGVMCVESVNREMSPLVDNI Canine $\quad 114$ EMSSQLHLTPFTARGRFATVVEELFRDGVNWGRIVAFFEFGGVMCVESVNREMS PLVDNI

$\begin{array}{llll}\text { Human } & 234 & \text { AYLGHK } & 239 \\ \text { Canine } & 234 & \text { AYLGHK } & 239 \\ \text { Murine } & 231 & \text { AYLGHK } & 236\end{array}$

Alignment for Bcl-xL (BCL2L1)

$\begin{array}{lll} & & \frac{\text { BH4 }}{\text { Human }} \\ \text { Canine } & 1 & \text { MSQSNRELVVDFLSYKLSQKGYSWSQFSDVEENRTEAPEGTESEMETPSA INGNPSWHLA } \\ \text { Murine } & 1 & \text { MSQSNRELVVDFLSYKLSQKGYSWSQFSDVEENRTEAPEGTESEMETPSA INGNPSWHLA } \\ \text { MSQSNRELVVDFLSYKLSQKGYSWSQFSDVEENRTEAPEETEAERETPSAINGNPSWHLA }\end{array}$

$\mathrm{BH} 3$

Human

Canine

Murine

61 DSPAVNGATGHSSSLDAREVIPMAAVKQALREAGDEFELRYRRAFSDLTSQLHITPGTAY 61 DSPAVNGATGHSSSLDAREVIPMAAVKQALREAGDEFELRYRRAFSDLTSQLHITPGTAY 61 DSPAVNGATGHSSSLDAREVIPMAAVKQALREAGDEFELRYRRAFSDLTSQLHITPGTAY

BH1

Human

Canine

QSFEQVVNELFRDGVNWGRIVAFFSFGGALCVESVDKEMQVLVSRIAAWMATYLNDHLEP QSFEQVVNELFRDGVNWGRIVAFFSFGGALCVESVDKEMQVLVSRIAAWMATYLNDHLEP QSFEQVVNELFRDGVNWGRIVAFFSFGGALCVESVDKEMQVLVSRIASWMATYLNDHLEP
60

60

60

120

120

120

180

180

180 
(Supplemental Figure S1 ctd.)

Alignment for Bcl-w (BCL2L2)

$\mathrm{BH} 4$

$\mathrm{BH} 3$

Human $\quad 1$ MATPASAPDTRALVADFVGYKLRQKGYVCGAGPGEGPAADPLHQAMRAAGDEFETRFRRT

Canine 1 MATPASAPDTRALVADFVGYKLRQKGYVCGAGPGEGPAADPLHQAMRAAGDEFETRFRRT

Murine $\quad 1$ MATPASTPDTRALVADFVGYKLRQKGYVCGAGPGEGPAADPLHQAMRAAGDEFETRFRRT

60

60

$\mathrm{BH} 1$

Human 61 FSDLAAQLHVTPGSAQQRFTQVSDELFQGGPNWGRLVAFFVFGAALCAESVNKEMEPLVG

Canine $\quad 61$ FSDLAAQLHVTPGSAQQRFTQVSDELFQGGPNWGRLVAFFVFGAALCAESVNKEMEPLVG

Murine

61 FSDLAAQLHVTPGSAQQRFTQVSDELFQGGPNWGRLVAFFVFGAALCAESVNKEMEPLVG

120

120

$\mathrm{BH} 2$

Human 121 QVQEWMVAYLETRLADWIHSSGGWAEFTALYGDGALEEARRLREGNWASVRTVLTGAVAL

Canine 121 QVQEWMVAYLETRLADWIHSSGGWAEFTALYGDGALEEARRLREGNWASVRTVLTGAVAL

180

Murine

121 QVQDWMVAYLETRLADWIHSSGGWAEFTALYGDGALEEARRLREGNWASVRTVLTGAVAL

180

Human 181 GALVTVGAFFASK 193

Canine 181 GALVTVGAFFASK 193

Murine 181 GALVTVGAFFASK 193 


\section{Alignment for Mcl-1}

$\begin{array}{lll}\text { Human } & 1 & \text { MFGLKRNAVIGLNLYCGGAGLGAGSGGATRPGGRLLATEKEASARREIGGGEAGAVIGGS } \\ \text { Canine } & 1 & \text { MFGLKRNAVIGLNLYCGGAGLGAGSGGASSSGGRLLASGKEATTRREGGGGEAGAVIGGS } \\ \text { Murine } & 1 & \text { MFGLRRNAVIGLNLYCGGASLGAGGGSPA--GARLVA--EEARARRE-GGGEA------- }\end{array}$

60

60

48

Human 61 AGASPPSTLTPDSRRVARPPIGAEVPDVTATPARLLFFAPTRRAAPLEEMEAPAADAIM Canine 61 AGASPPTTLAPDARRVARPSPIGAEGPNVSATPPRLLLLAPPCRASPPEEMEGPAADAIM Murine $49-------A L L P G A R V V A R P P P V G A E D P D V T A S A E R R L H K S P G L L A V P P E E M A A S A A A A I V$

\section{PS}

PS

Human 121 SPEEELDGYEPEPLGKRPAVLPLLELVGESGNNTSTDGSLPSTPPPAEEEEDELYRQSLE

Canine SPEEELDGYEPEPLGKRPAVLPLLELVGEASSGPGMDGSLPSTPPPAEEEEDELYRQSLE

Murine

102 SPEEELDGCEPEAIGKRPAVLPLLERVSEAAKSSGADGSLPSTPPPPEEEEDDLYRQSLE

\section{$\mathrm{BH} 3$}

Human 181 IISRYLREQATGAKDTKPMGRSGATSRKALETLRRVGDGVQRNHETAFQGMLRKLDIKNE

Canine 181 IISRYLREQATGAKDAKPLGGSRAASRKALETLRRVGDGVQRNHETAFQGMLRKLDIKNE

Murine 162 IISRYLREQATGSKDSKPLGEAGAAGRRALETLRRVGDGVQRNHETAFQGMLRKLDIKNE

BH1

Human

Canine

DDVKSLSRVMI HVF SDGVTNWGRIVTLISFGAFVAKHLKT INQESCIEPLAESITDVLVR DDVKSLSRVIVHVFSDGVTNWGRIVTLISFGAFVAKHLKS INQESCIEPLAESITDVLVR

Murine
TM

Human 301 TKRDWLVKQRGWDGFVEFFHVEDLEGG $\overline{\text { IRNVLLAFAGVAGVGAGLAYLIR }} 350$

Canine 301 TKRDWLVKQRGWDGFVEFFHVEDLEGGIRNVLLAFAGVAGVGAGLAYLIR 350

Murine 282 TKRDWLVKORGWDGFVEFFHVODLEGGIRNVLLAFAGVAGVGAGLAYLIR 331 


\section{Alignment for Bak}

Human $\quad 1$ MASGQGPGPPRQECGEPALPSASEEQVAQDTEEVFRSYVFYRHQQEQEAEGVAAPADPEM

Canine 1 MASGQGPGPPRRECGEAAPSSTSEEQVARDTEEVFRSYVFYRHRQEQEAEGAAVPADPEM

Murine $\quad 1$ MASGQGPGPPKVGCDES--PSPSEQQVAQDTEEVFRSYVFYLHQQEQETQGAAAPANPEM

60

60

58

$\mathrm{BH} 3$

Human 61 VTLPLQPSSTMGQVGRQLAIIGDDINRRYDSEFQTMLQHLQPTAENAYEYFTKIATSLFE Canine $\quad 61$ VTLPLEPSSTMGQVGRQLAI IGDD INQRYDSEFQAMLQHLQPTAENAYEYFTKIASSLFE

Murine

59 DNLPLEPNSILGQVGRQLALIGDDINRRYDTEFQNLLEQLQPTAGNAYELFTKIASSLFK

120

120

118

BH1

$\mathrm{BH} 2$

Human 121 SGINWGRVVALLGFGYRLALHVYQHGLTGFLGQVTRFVVDFMLHHCIARWIAQRGGWVAA Canine 121 SGINWGRVVALLGFGYRLALHVYQRGLTGFLGQVTRFVADFMLHHCIARWIAQRGGWVAA

Murine 119 SGISWGRVVALLGFGYRLALYVYQRGLTGFLGQVTCFLADIILHHYIARWIAQRGGWVAA

180

180

178

Human 181 LNLGNGPILNVLVVLGVVLLGQFVVRRFFKS 211

$\begin{array}{llll}\text { Canine } & 181 & \text { LNLGNGPILNVLIVLSVVLLGQFVVRRFFKS } & 211\end{array}$

$\begin{array}{lll}\text { Murine } & 179 & \text { LNFRRDPILTVMVIFGVVLLGQFVVHRFFRS } 209\end{array}$

\section{Alignment for Bax var. alpha}

Human 1 MDGSGEQPRGGGPTSSEQIMKTGALLLQGFIQDRAGRMGGEAPELALDPVPQDASTKKLS

Canine $\quad 1$ MDGSGEQPRGGGPTSSEOIMKTGALLLOGFIODRAGRMGGETPELPLEOVPODASTKKLS

Murine 1 MDGSGEQLGSGGPTSSEQIMKTGAFLLQGFIQDRAGRMAGETPELTLEQPPQDASTKKLS

60

60

60

$\mathrm{BH} 3$

BH1

Human 61 ECLKRIGDELDSNMELQRMIAAVDTDS PREVFFRVAADMFSDGNFNWGRVVALFYFASKL

Canine

Murine

61 ECLKRIGDELDSNMELQRMIAAVDTDSPREVFFRVAAEMFSDGNFNWGRVVALFYFASKL

61 ECLRRIGDELDSNMELQRMIADVDTDS PREVFFRVAADMFADGNFNWGRVVALFYFASKL

120

120

120

$\mathrm{BH} 2$

Human 121 VLKALCTKVPELIRTIMGWTLDFLRERLLGWIQDQGGWDGLLSYFGTPTWQTVTIFVAGV

Canine 121 VLKALCTKVPELIRTIMGWTLDFLRERLLGWIQDQGGWDGLLSYFGTPTWQTVTIFVAGV

Murine 121 VLKALCTKVPELIRTIMGWTLDFLRERLLVWIODQGGWEGLLSYFGTPTWOTVTIFVAGV

180

180

180

$\begin{array}{llll}\text { Human } & 181 & \text { LTASLTIWKKMG } & 192 \\ \text { Canine } & 181 & \text { LTASLTIWKKMG } & 192 \\ \text { Murine } & 181 & \text { LTASLTIWKKMG } & 192\end{array}$




\section{Alignment for Bad}

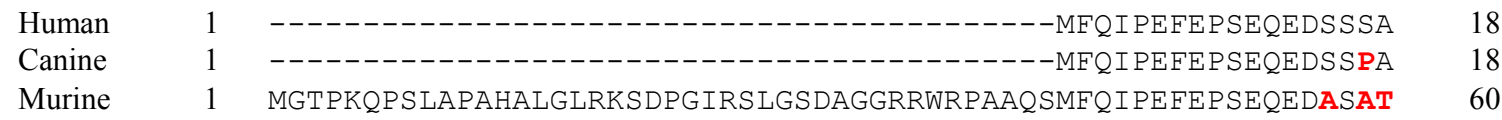

PS

Human 19 ERGLGPSPAGDGPSGSGKHHRQAPGLLWDASHQQEQPTSSSHHGGAGAVEIRSRHSSYPA 78

Canine $\quad 19$ NRGLGPSPTGDRPPSPGKHQQTAPGLLGEAGHQQGQPASRKHHGGAGA-ETRSRHSSFPA 77

Murine 61 DRGLGPSLTEDQP---GPY--LAPGLLGSNIHQQGRAATNSHHGGAGAMETRSRHSSYPA 115

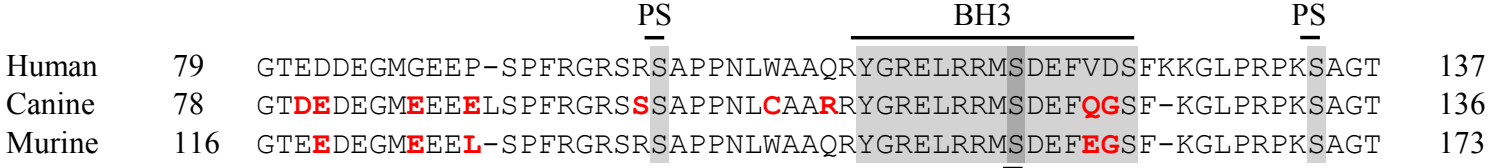

PS

$\begin{array}{llll}\text { Human } & 138 & \text { ATQMRQSSSWTRVFQSWWDRNLG------- } & 160 \\ \text { Canine } & 137 & \text { ATQMRQSPSWTRVIQSWWDRNLGRGGSAPSQ } & 167 \\ \text { Murine } & 174 & \text { ATQMRQSAGWTRIIQSWWDRNLGKGGSTPSQ } & 204\end{array}$

Alignment for Noxa (PMAIP1)

Human 1 - 1 -

1 1

Murine $\quad 1$ MPGRKARRNAPVNPTRAELPPEFAAQLRKIGDKVYCTWSAPDITVVLAQMPGKSQKSRMR 60

\begin{tabular}{|c|c|c|c|c|c|}
\hline & & & $\mathrm{BH} 3$ & MTD & \\
\hline & 12 & -PSPARAPAELE & QLRRFGDKLNF & RQKLLNLISKLFCSGT & 54 \\
\hline tet & 12 & -PGPTRAPEELE & VECAIQLRKFGDKLNF & RQKLLNLLSKLFRSGT & \\
\hline 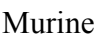 & 61 & SPSPTRVPADLK & DECA-QLRRIGDKVNL & RQKLLNLISKLFNLVT & 103 \\
\hline
\end{tabular}

\section{Legend:}

Alignments are slightly modified from a CLUSTAL format alignment by MAFFT (v7.182)

Non-identical amino acids are labelled in bold red;

domains (labelled in gray): $\mathrm{BH} 1, \mathrm{BH} 2, \mathrm{BH} 3, \mathrm{BH} 4=\mathrm{Bcl}-2$ Homology Domain 1 to 4 ; $\mathrm{TM}=$ Transmembrane domain; MTD = Mitochondrial Targeting Domain; PS = phosphorylation site (Serine or Threonine residues) 


\section{Figure legends}

Fig. 1 Interspecies conservation of protease (caspase and calpain) recognition motifs in indicated Bcl-2 family members.

Fig. 2 Growth curves of yeast expressing Bcl-2 family proteins grown in minimal inducing medium. A: expression of proapoptotic proteins Bak and Bax impose marked growth retardation. B: co-expression of anti-apoptotic Bcl-2 family proteins abrogates the growth retardation effect of Bak and Bax. The curves are deduced from $\mathrm{OD}_{600}$ measurements at $6 \mathrm{~h}$ intervals and are representative of two independent experiments.

Fig. 3 Clonogenic assay of yeast cultures induced to express different Bcl-2 family proteins by growth in liquid galactose media for $24 \mathrm{~h}$ (a) and $48 \mathrm{~h}$ (b), followed by plating on noninducing, glucose containing, solid media, and growth for $72 \mathrm{~h}$ at $30{ }^{\circ} \mathrm{C}$. The columns indicate the mean value and standard error of the mean (SEM) of at least three independent experiments. Expression of Bak and Bax results in massively reduced clonogenicity. This effect is more pronounced after protein expression of $48 \mathrm{~h}(\mathrm{~b})$ compared to $24 \mathrm{~h}$ (a) and is abrogated by coexpression of anti-apoptotic proteins. Values for Bax and Bak are significantly different from all other values $\left(* * \mathrm{p}<0.0001,{ }^{*} \mathrm{P}=0.019\right.$, student's $\mathrm{t}$ test $)$.

Fig. 4 Western blots of yeasts transformed with plasmids containing the indicated canine Bcl-2 family cDNAs, cultured in liquid inducing medium for $24 \mathrm{~h}$ and labelled with the indicated antibodies. Relevant marker sizes are indicated. (a): lane 1, vector only; lane 2, Bclw; lane 3, Bcl-w+Bak; lane 4, Bcl-w+Bax; lane 5, Bcl-x+Bak; lane 6, Bcl-x+Bax, lane 7, 
Mcl-1+Bak; lane 8, Mcl-1+Bax. (b): lane 1, vector only; lane 2, Bcl-w. (c): lane 1, vector only; lane 2, Bcl-x. (d): lane 1, vector only; lane 2, Mcl-1. 
Figure 1

\begin{tabular}{|c|c|c|c|}
\hline Bcl-2 & Bax & Bad & \\
\hline casp-3 cleavage site & calpain recognition motif & major casp- 3 cleavage site & minor casp -3 cleavage site ${ }^{4}$ \\
\hline D A G D lla (34) & F I Q D latas; & E $\quad$ Q $\quad$ E $\quad D^{H=(14)}$ & \begin{tabular}{l|l|l}
$S$ & A & E Was
\end{tabular} \\
\hline \begin{tabular}{l|ll|l} 
& D & G & E
\end{tabular} & $\begin{array}{llll} & \text { I } & \text { Q } & \text { D }\end{array}$ & E Q E $\quad$ E $\quad$ D $\cos (14)$ & \begin{tabular}{l|l|l|l} 
& $\mathrm{P}$ & $\mathrm{A}$ & $\mathrm{N}$
\end{tabular} \\
\hline D A G D wa (34) & F I Q D vass & 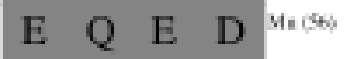 & $\mathrm{S}$ A T D Mals \\
\hline Bcl-XL & & Mcl-1 & \\
\hline casp-1/-3 cleavage site & casp -3 cleavage site & major casp-3 cleavage site & minor casp-3 cleavage site \\
\hline H L A D la (6) & S $\quad S \quad L \quad D^{\text {Ha }}(T)$ & E E L D He(12T) & $\mathrm{T} \quad \mathrm{S} \quad \mathrm{T} \quad \mathrm{D}$ He(19T) \\
\hline H L A D Cusply & S S L D & E E L D $\mathrm{CO}_{(127)}$ & P $\quad$ G $\quad$ M $\quad$ D \\
\hline H L A D satols & $\begin{array}{lllll}S & S & \text { L Ma }\end{array}$ & E E L D Mactess & S G A D Me $135 \%$ \\
\hline
\end{tabular}

Bold: substrate; plain: specific tetramer recognition site; Hu: human; Ca: canine; Mu: murine, number in parentheses refer to position of the fourth amino acid, which directly precedes the caspase cleavage site; residues in grey are identical to human sequence; "minor caspase-3 recognition site described in murine Bad. 
Figure 2a

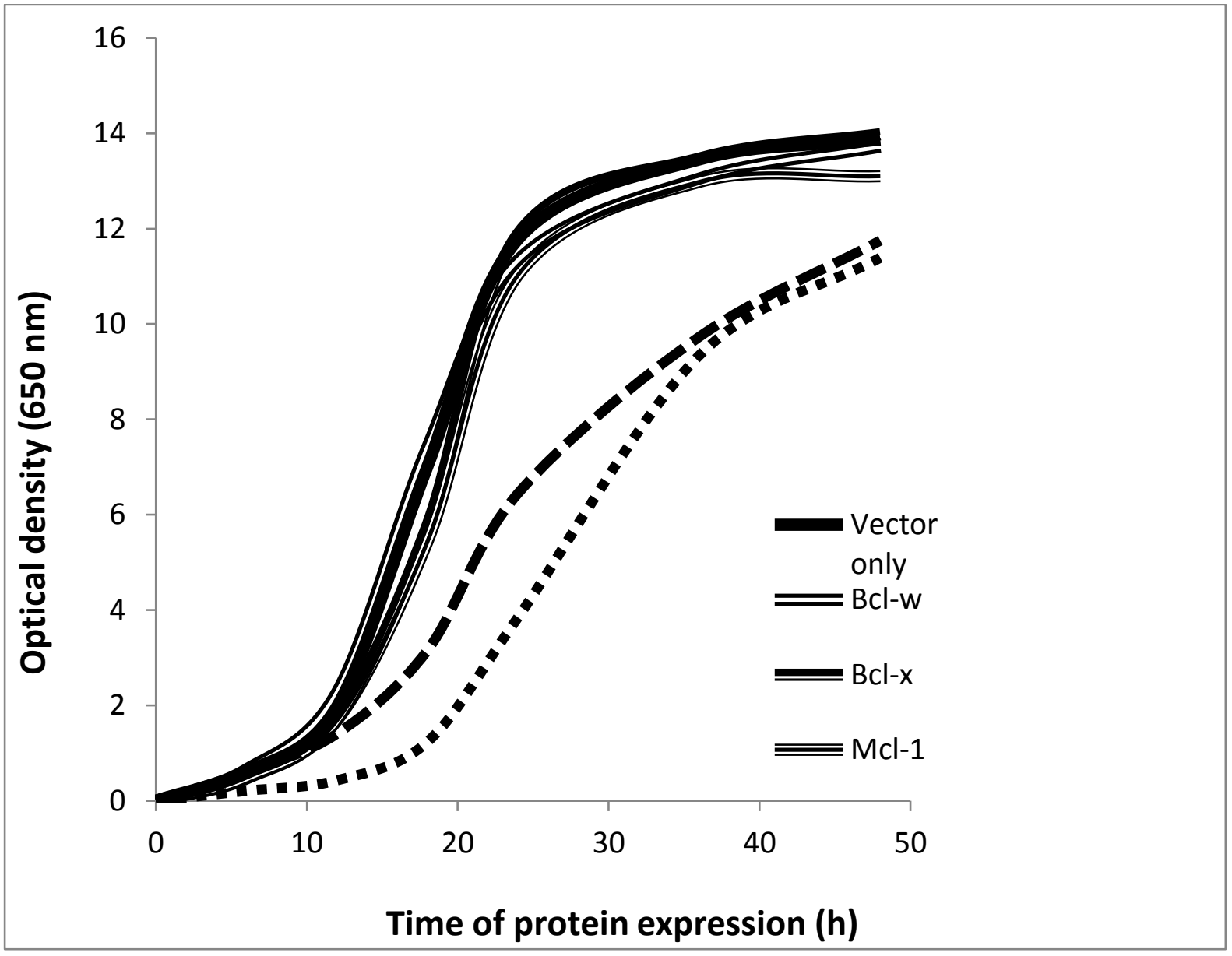


Figure $2 b$

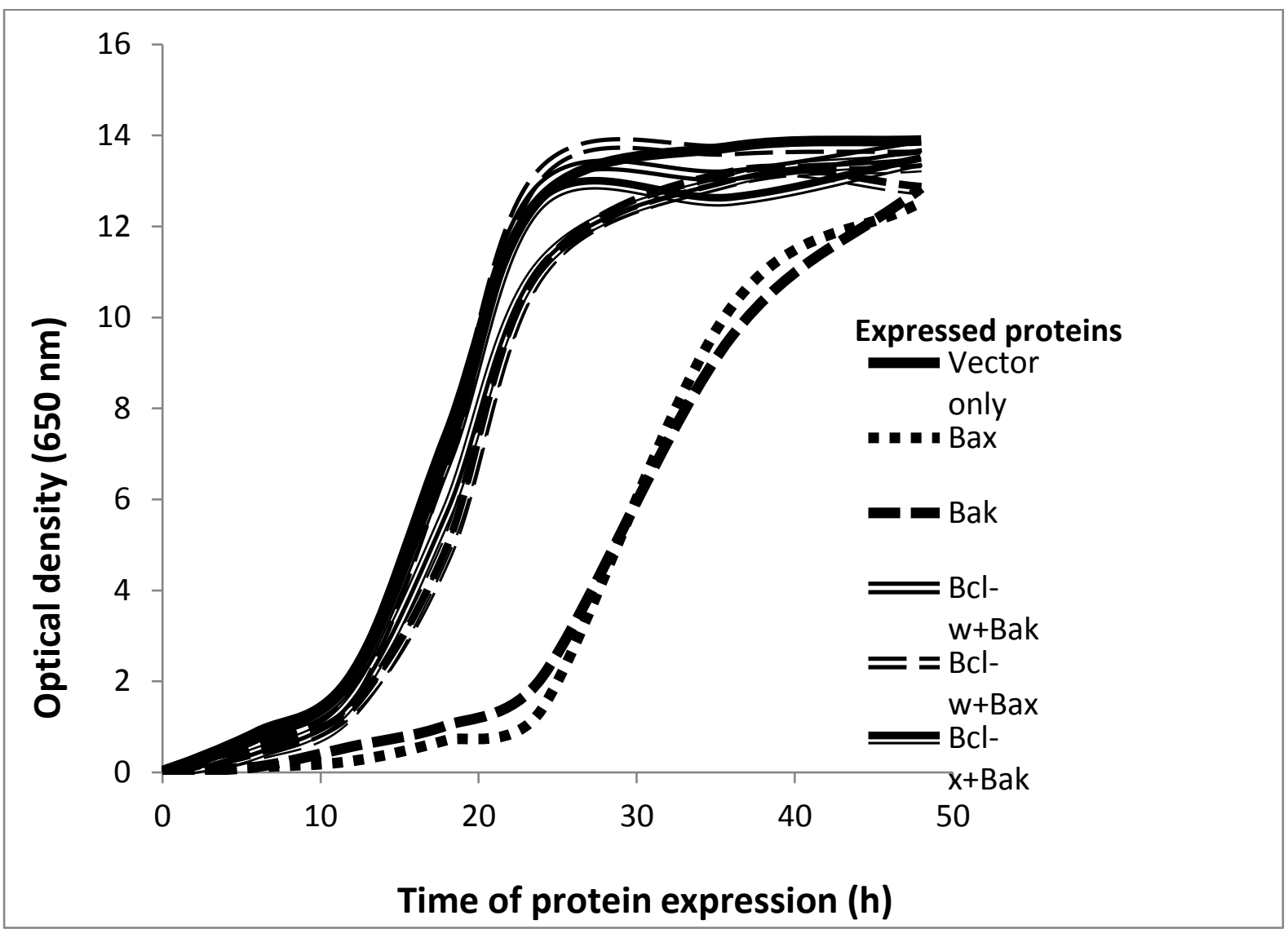


Figure 3a

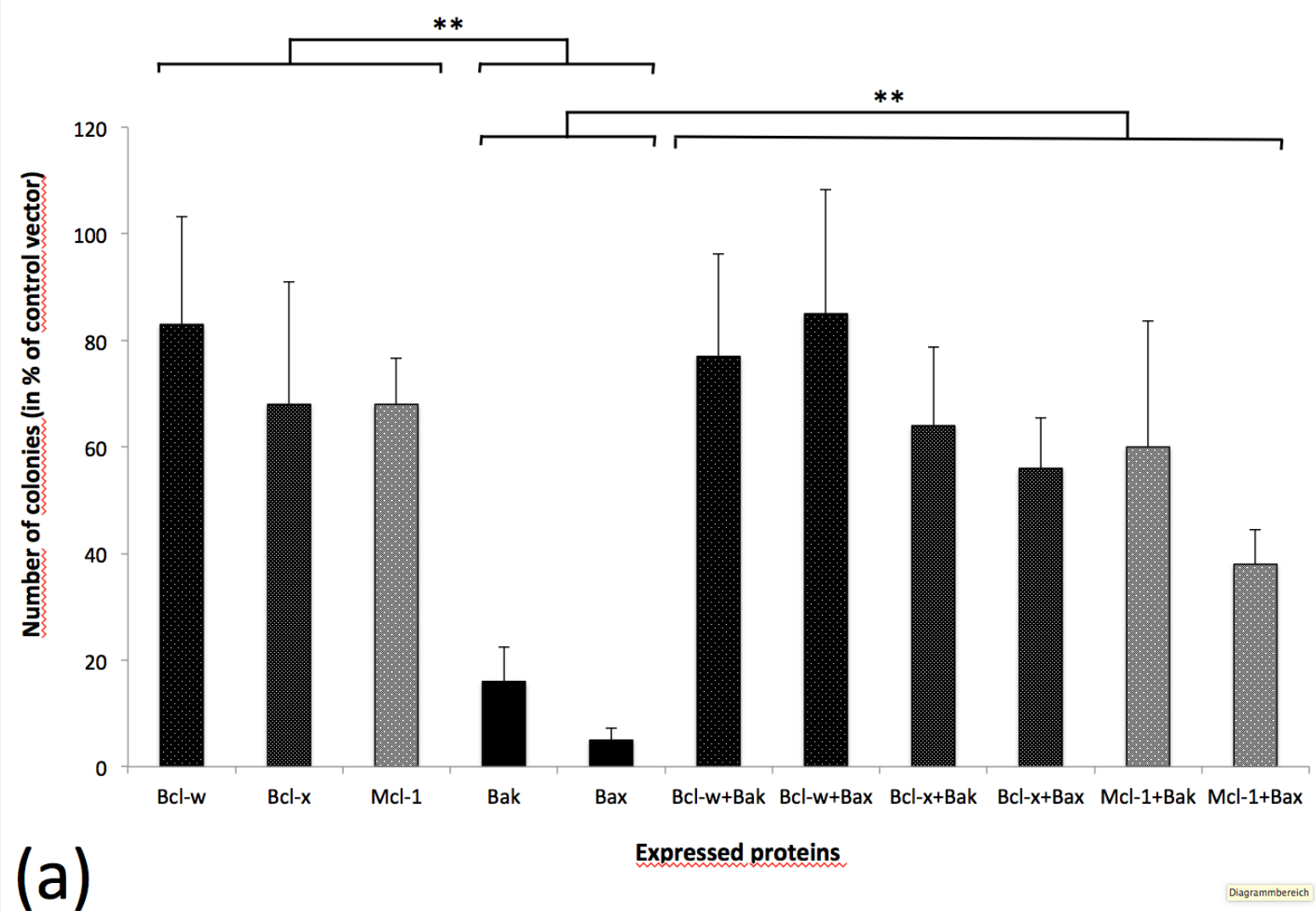


Figure $3 b$

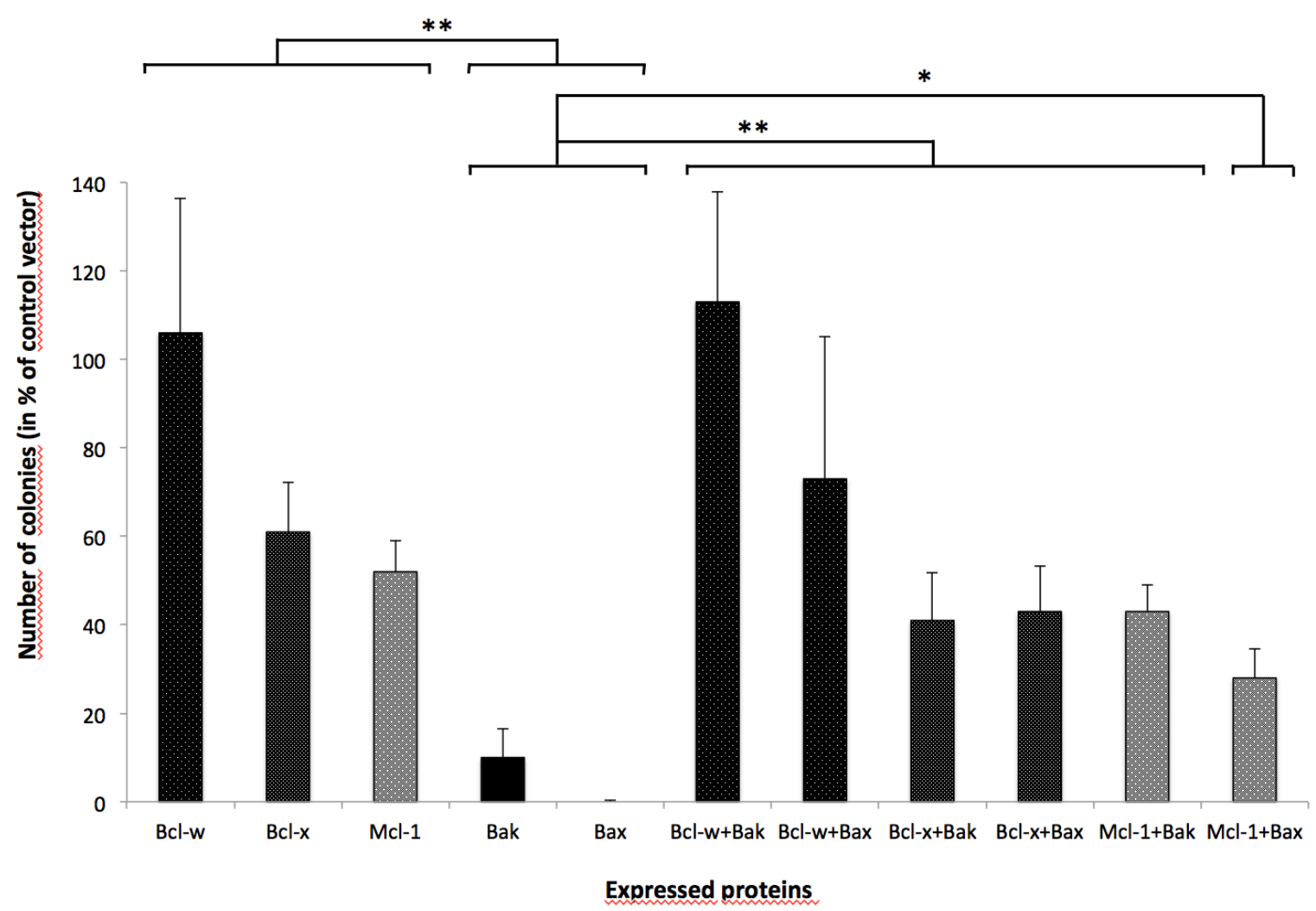

(b) 
Figure 4

(a)
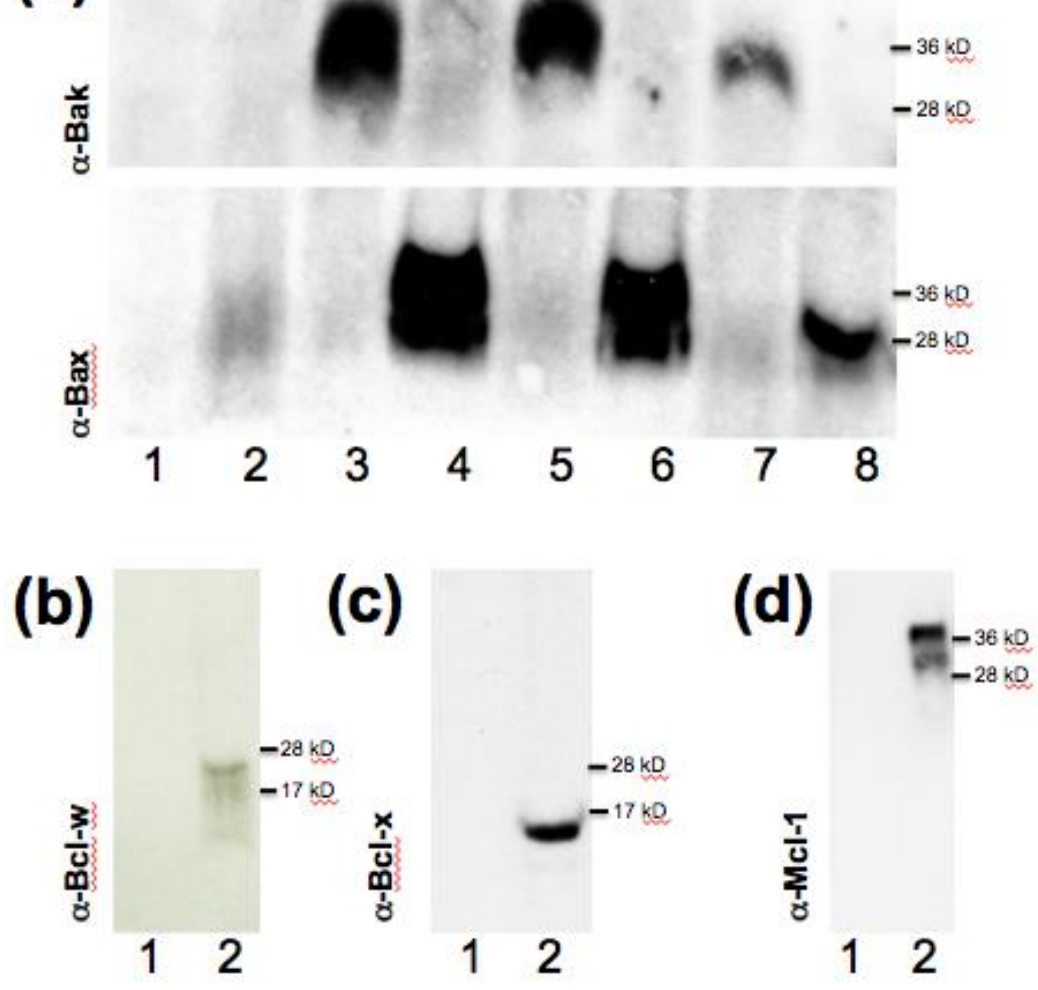
Table 1. Primers for amplification of canine Bcl-2 family cDNAs

Molecule $\quad$ Forward primer $\quad$ Reverse primer

\begin{tabular}{|c|c|c|}
\hline Bcl- $x_{L}(B C L 2 L 1)$ & 5`-ССАТСССТАТTAТАAАAATGTCTCA-3’ & 5'-GGGTAAGTGGGTGGTCAGTG-3`* \\
\hline Bc1-w (BCL2L2) & 5'-GGATGGCGACCCCAGCC-3’ & 5'-GCTCACTTGCTCGCAAAAAAG-3’ \\
\hline Mcl-1 & 5'-AGGAGCTTGCGATGTTCGG-3’ & 5'-CACTTAAAAGGCTATCTTATTAG-3’ \\
\hline Bak & 5'-GAGAAATGGCATCCGGGC-3’ & 5'-CCTCTGGGAGTCATGATTTG-3’ \\
\hline Bax var. alpha & 5'-TGATGGACGGGTCCGGGG-3’ & 5'-GGCCTCAGCCCATCTTTTTC-3’ \\
\hline Bad & 5'-AGAGCATGTTCCAGATCCC-3’ & 5'-GGACGCGGGACGGGTCAC-3` \\
\hline Noxa (PMAIP1) & 5'-AGATGCCCGGCCGGAAG-3’ & 5'-ATCAAGGTTCCTGAGCGGAAG-3’ \\
\hline
\end{tabular}

Start- and stop-codons are indicated in bold

* Stop-codon is upstream of primer sequence 
Table 2. Accession numbers of Bcl-2 family members used in this study

\begin{tabular}{|c|c|c|c|}
\hline \multirow[b]{2}{*}{ Molecule } & \multicolumn{3}{|c|}{ Nucleotide and protein sequence accession number for indicated species } \\
\hline & Human $^{1}$ & Canine $^{2}$ & Murine $^{1}$ \\
\hline Bcl-2 isoform alpha & NM_000633.2, NP_000624.2 & AB154172.1, BAD05044.1 & NM_009741.4, NP_033871.2 \\
\hline $\mathrm{Bcl}-\mathrm{x}_{\mathrm{L}}(\mathrm{BCL} 2 \mathrm{~L} 1)$ & NM_138578.1, NP_612815.1 & АВ073983.1, ВАВ71819.1 & NM_009743.5, NP_033873.3 \\
\hline Bcl-w (BCL2L2) & NM_004050.4, NP_004041.1 & DQ116955.13 ${ }^{3}$, AAZ22484.13 & NM_007537.1, NP_031563.1 \\
\hline Mcl-1 & NM_021960.4, NP_068779.1 & AB093582.2, BAC21258.1 & NM_008562.3, NP_032588.1 \\
\hline Bak & NM_001188.3, NP_001179.1 & DQ002813.1 ${ }^{3}, \mathrm{AAY} 19401.1^{3}$ & NM_007523.2, NP_031549.2 \\
\hline Bax variant alpha & NM_138761.3, NP_620116.1 & AB080230.1, BAC53619.1 & NM_007527.3, NP_031553.1 \\
\hline Bad & NM_004322.3, NP_004313.1 & DQ127247.1 $1^{3}, \mathrm{AAZ} 32936.1^{3}$ & NM_007522.3, NP_031548.1 \\
\hline Noxa (PMAIP1) & NM_021127.2, NP_066950.1 & DQ449072.1 ${ }^{3}, \mathrm{ABE} 02691.1^{3}$ & NM_021451.2, NP_067426.1 \\
\hline
\end{tabular}

${ }^{1}$ Reference Sequences available at NCBI

${ }^{2}$ GenBank accession numbers

${ }^{3}$ Own submission 
Table 3. Interspecies comparison of Bcl-2 family members coding sequences

\begin{tabular}{|c|c|c|c|c|c|}
\hline \multirow[t]{2}{*}{ Molecule } & \multicolumn{3}{|c|}{$\begin{array}{l}\text { No. of coding } \\
\text { exons }\end{array}$} & \multicolumn{2}{|c|}{$\begin{array}{l}\text { Coding sequence } \\
\text { identity }\end{array}$} \\
\hline & $\mathrm{Hu}$ & $\mathrm{Ca}$ & $\mathrm{Mu}$ & $\mathrm{Hu} / \mathrm{Ca}$ & $\mathrm{Hu} / \mathrm{Mu}$ \\
\hline $\mathrm{Bcl}-2$ isoform alpha & 2 & $?$ & 2 & $92 \%$ & $89 \%$ \\
\hline $\mathrm{Bcl}-\mathrm{x}_{\mathrm{L}}$ (BCL2L1) & 2 & 2 & 2 & $97 \%$ & $94 \%$ \\
\hline Bcl-w (BCL2L2) & 2 & 2 & 2 & $95 \%$ & $94 \%$ \\
\hline Mcl-1 & 3 & 3 & 3 & $89 \%$ & $83 \%$ \\
\hline Bak & 5 & 5 & 5 & $90 \%$ & $80 \%$ \\
\hline Bax variant alpha & 6 & $?$ & 6 & $93 \%$ & $90 \%$ \\
\hline $\mathrm{Bad}$ & 3 & 3 & 4 & $86 \%$ & $65 \%$ \\
\hline Noxa & 2 & 2 & 3 & $87 \%$ & $40 \%$ \\
\hline
\end{tabular}

$\mathrm{Hu}$ : human; Ca: canine; $\mathrm{Mu}$ : murine

?: alignment to genome sequence incomplete 
Table 4.

Table 4. Interspecies comparison of Bcl-2 family protein sequences

\begin{tabular}{|c|c|c|c|c|c|c|c|c|c|c|}
\hline \multirow[b]{2}{*}{ Molecule } & \multicolumn{3}{|c|}{ Protein length ${ }^{1}$} & \multicolumn{2}{|c|}{ Whole protein homology ${ }^{2}$} & \multirow[b]{2}{*}{ Domain $^{3}$} & \multicolumn{2}{|c|}{ Domain homology ${ }^{2} \mathrm{Hu} / \mathrm{Ca}$} & \multicolumn{2}{|c|}{ Domain homology ${ }^{2} \mathrm{Hu} / \mathrm{Mu}$} \\
\hline & $\mathrm{Hu}$ & $\mathrm{Ca}$ & $\mathrm{Mu}$ & $\begin{array}{l}\mathrm{Hu} / \mathrm{Ca} \text { (Identities; } \\
\text { similarities) }\end{array}$ & $\begin{array}{l}\mathrm{Hu} / \mathrm{Mu} \text { (Identities; } \\
\text { similarities) }\end{array}$ & & Identities & Similarities $^{4}$ & Identities & Similarities $^{4}$ \\
\hline \multirow[t]{6}{*}{ Bcl-2 isoform alpha } & 239 & 239 & 236 & $\begin{array}{l}219 / 246(89 \%) \\
222 / 246(90 \%)\end{array}$ & $\begin{array}{l}\text { 217/239 (91\%); } \\
219 / 239(92 \%)\end{array}$ & BH 1 & $20 / 20(100 \%)$ & - & $20 / 20 / 100 \%)$ & - \\
\hline & & & & & & BH 2 & $16 / 16(100 \%)$ & - & $16 / 16(100 \%)$ & - \\
\hline & & & & & & BH 3 & $15 / 15(100 \%)$ & - & $14 / 15(93 \%)$ & $15 / 15(100 \%)$ \\
\hline & & & & & & BH 4 & $21 / 21(100 \%)$ & - & $21 / 21(100 \%)$ & - \\
\hline & & & & & & $\mathrm{TM}$ & $21 / 22(95 \%)$ & - & $22 / 22(100 \%)$ & - \\
\hline & & & & & & PS & $1 / 1(100 \%)$ & - & $1 / 1(100 \%)$ & - \\
\hline \multirow[t]{5}{*}{ Bel-XL (BCL2L1) } & 233 & 233 & 233 & $233 / 233(100 \%)$ & $\begin{array}{l}228 / 233(98 \%) \\
231 / 233(99 \%)\end{array}$ & BH 1 & $20 / 20(100 \%)$ & - & $20 / 20(100 \%)$ & - \\
\hline & & & & & & BH 2 & $16 / 16(100 \%)$ & $\cdot$ & $15 / 16(94 \%)$ & $16 / 16(100 \%)$ \\
\hline & & & & & & BH 3 & $15 / 15(100 \%)$ & - & $15 / 15(100 \%)$ & - \\
\hline & & & & & & BH 4 & $21 / 21(100 \%)$ & - & $21 / 21(100 \%)$ & - \\
\hline & & & & & & $\mathrm{TM}$ & $17 / 17(100 \%)$ & - & $17 / 17(100 \%)$ & - \\
\hline \multirow[t]{5}{*}{ Bcl-w (BCL2L2) } & 193 & 193 & 193 & 193/193 (100\%) & $\begin{array}{l}\text { 191/193 (99\%); } \\
192 / 193(99 \%)\end{array}$ & BH 1 & $20 / 20(100 \%)$ & $\cdot$ & $20 / 20(100 \%)$ & - \\
\hline & & & & & & BH 2 & $16 / 16(100 \%)$ & - & $16 / 16(100 \%)$ & - \\
\hline & & & & & & BH 3 & $15 / 15(100 \%)$ & - & $15 / 15(100 \%)$ & - \\
\hline & & & & & & BH 4 & $21 / 21(100 \%)$ & - & $21 / 21(100 \%)$ & - \\
\hline & & & & & & $\mathrm{TM}$ & $21 / 21(100 \%)$ & & $21 / 21(100 \%)$ & - \\
\hline \multirow[t]{5}{*}{ Mcl-1 } & 350 & 350 & 331 & $\begin{array}{l}312 / 350(89 \%) \\
326 / 350(93 \%)\end{array}$ & $\begin{array}{l}267 / 350(76 \%) \\
290 / 350(83 \%)\end{array}$ & BH 1 & $21 / 21(100 \%)$ & $\cdot$ & $20 / 21$ (95\%) & - \\
\hline & & & & & & BH 2 & $16 / 16(100 \%)$ & $\cdot$ & $16 / 16(100 \%)$ & - \\
\hline & & & & & & BH 3 & $15 / 15(100 \%)$ & - & $15 / 15(100 \%)$ & - \\
\hline & & & & & & TM & $21 / 21(100 \%)$ & - & $21 / 21(100 \%)$ & - \\
\hline & & & & & & PS & $2 / 2$ (100\%) & - & $2 / 2(100 \%)$ & - \\
\hline \multirow[t]{4}{*}{ Bak } & 211 & 211 & 209 & $\begin{array}{l}\text { 194/211 (92\%); } \\
201 / 211(95 \%)\end{array}$ & $\begin{array}{l}\text { 162/211 (77\%); } \\
182 / 211(86 \%)\end{array}$ & BH 1 & $20 / 20(100 \%)$ & - & $18 / 20$ (90\%) & $20 / 20(100 \%)$ \\
\hline & & & & & & BH 2 & $16 / 16(100 \%)$ & - & $14 / 16(87 \%)$ & $14 / 16(87 \%)$ \\
\hline & & & & & & BH 3 & $14 / 15(93 \%)$ & $15 / 15(100 \%)$ & $14 / 15(93 \%)$ & $15 / 15(100 \%)$ \\
\hline & & & & & & TM & $16 / 18(89 \%)$ & $17 / 18(94 \%)$ & $14 / 18(78 \%)$ & $16 / 18(89 \%)$ \\
\hline \multirow[t]{4}{*}{ Bax var. alpha } & 192 & 192 & 192 & $\begin{array}{l}\text { 187/192 (97\%); } \\
\text { 189/192 (98\%) }\end{array}$ & $\begin{array}{l}\text { 177/192 (92\%); } \\
\text { 181/192(94\%) }\end{array}$ & BH 1 & $20 / 21$ (95\%) & $21 / 21(100 \%)$ & $20 / 21$ (95\%) & $21 / 21(100 \%)$ \\
\hline & & & & & & BH 2 & $16 / 16(100 \%)$ & - & $14 / 16(87 \%)$ & $15 / 16(94 \%)$ \\
\hline & & & & & & BH 3 & $15 / 15(100 \%)$ & - & $14 / 15(93 \%)$ & $15 / 15(100 \%)$ \\
\hline & & & & & & $\mathrm{TM}$ & $21 / 21(100 \%)$ & - & $21 / 21(100 \%)$ & - \\
\hline \multirow[t]{2}{*}{ Bad } & 160 & 167 & 204 & $\begin{array}{l}128 / 169(76 \%) \\
134 / 169(79 \%)\end{array}$ & $\begin{array}{l}122 / 210(58 \%) \\
133 / 210(63 \%)\end{array}$ & BH 3 & $13 / 15(87 \%)$ & $\cdot$ & $13 / 15(87 \%)$ & - \\
\hline & & & & & & PS & $4 / 4(100 \%)$ & $\cdot$ & $4 / 4(100 \%)$ & - \\
\hline \multirow[t]{2}{*}{ Noxa (PMAIP1) } & 54 & 54 & 103 & $\begin{array}{l}\text { 45/54 (83\%); } \\
49 / 54(91 \%)\end{array}$ & $\begin{array}{l}35 / 104(34 \%) \\
40 / 104(38 \%)\end{array}$ & BH 3 & $13 / 15(87 \%)$ & $14 / 15(93 \%)$ & $11 / 15(73 \%)$ & $12 / 15(80 \%)$ \\
\hline & & & & & & MTD & $9 / 10(90 \%)$ & $10 / 10(100 \%)$ & $10 / 10(100 \%)$ & $\cdot$ \\
\hline \multicolumn{11}{|c|}{ The number of amino acids is indicated; Hu: human; Ca: canine; Mu: murine } \\
\hline \multicolumn{11}{|c|}{${ }^{2}$ Identities refer to number/percentage of identical amino acids; Similarities further include amino acids with similar properties } \\
\hline \multicolumn{11}{|c|}{${ }^{3}$ BH: Bcl-2 homology domain; TM: Transmemberane domain; PS: phosphorylation site (Serine or Threonine residues); MTD: Mitochondrial targeting domain } \\
\hline
\end{tabular}

